\title{
Efficient and flexible synthesis of new photoactivatable propofol analogs
}

Kenneth A. Skinner ${ }^{\mathrm{a}, \mathrm{b}}$, Joseph S. Wzorek ${ }^{\mathrm{c}, \mathrm{d}}$, Daniel Kahne ${ }^{\mathrm{a}, \mathrm{d}}$ and Rachelle Gaudet ${ }^{\mathrm{a}, *}$

${ }^{a}$ Department of Molecular and Cellular Biology, Harvard University, Cambridge, MA 02138, USA.

${ }^{\mathrm{b}}$ Present address: Departments of Medicine and Pharmacology, University of California, San Diego, La Jolla 92161, USA.

c Present address: Novartis Institutes for BioMedical Research, Cambridge, MA 02139, USA.

${ }^{\mathrm{d}}$ Department of Chemistry and Chemical Biology, Harvard University, Cambridge, MA 02138, USA.

* Corresponding author: gaudet@mcb.harvard.edu

\section{Graphical Abstract}
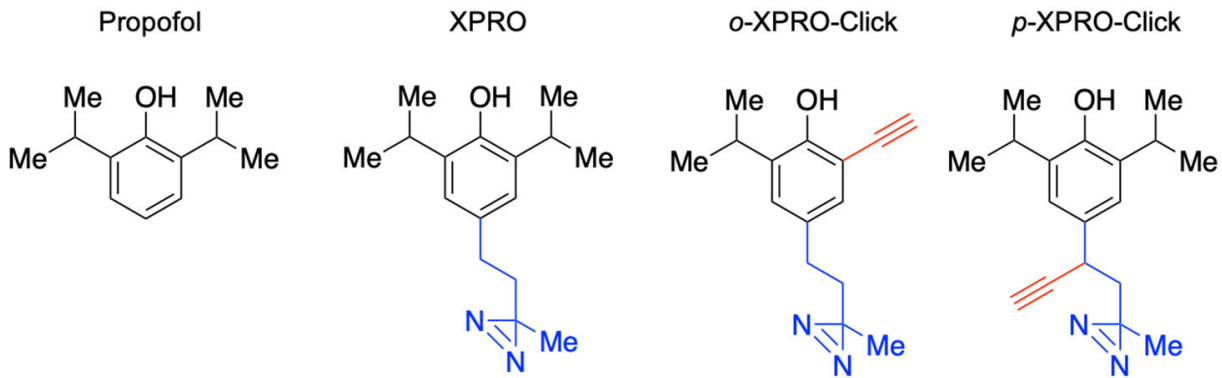

Clickable handle

Diazirine crosslinker

\section{Keywords}

Propofol; TRPA1; Diazirine; Click chemistry

\begin{abstract}
Propofol is a widely used general anesthetic, which acts by binding to and modulating several neuronal ion channels. We describe the synthesis of photoactivatable propofol analogs functionalized with an alkyne handle for bioorthogonal chemistry. Such tools are useful for detecting and isolating photolabeled proteins. We designed expedient and flexible synthetic routes to three new diazirine-based crosslinkable propofol derivatives, two of which have alkyne handles. As a proof of principle, we show that these compounds activate heterologously expressed Transient Receptor Potential Ankyrin 1 (TRPA1), a key ion channel of the pain pathway, with a similar potency as propofol in fluorescence-based functional assays. This work demonstrates that installation of the crosslinkable and clickable group on a short nonpolar spacer at the para position of propofol does not affect TRPA1 activation, supporting the utility of these chemical tools in identifying and characterizing potentially druggable binding sites in propofolinteracting proteins.
\end{abstract}


Propofol (2,6-diisopropylphenol) is an intravenous general anesthetic used in millions of surgical procedures worldwide. ${ }^{1}$ In addition to the sedative effects it exerts on the central nervous system, propofol also elicits a "burning" sensation upon injection in many patients. ${ }^{2}$ The $\gamma$-aminobutyric acid $\mathrm{A}\left(\mathrm{GABA}_{\mathrm{A}}\right)$ receptor is the principal target leading to the anesthetic properties of propofol, ${ }^{3}$ whereas Transient Receptor Potential Ankyrin 1 (TRPA1), a calcium-permeable ion channel expressed in peripheral sensory neurons, has been suggested to be the key mediator of propofolinduced pain. ${ }^{4}$ We recently used a photocrosslinkable propofol analog to demonstrate that this analog does indeed bind in the TRPA1 site identified by mutagenesis. ${ }^{5-7}$ Similar strategies have identified propofol-binding sites in the GABAA receptor. ${ }^{8,9}$ These studies illustrate the power of photoaffinity labeling (PAL) to identify the binding-site location in complex biological systems, particularly where multiple binding sites may exist. ${ }^{5,6}$ In addition, PAL probes may elucidate new drug targets and off-target proteins, facilitating drug discovery efforts. ${ }^{10,11}$

PAL finds widespread utility in drug discovery as a method to identify new macromolecular targets and as a complement to structure determination techniques like cryo-EM and X-ray crystallography to probe the location and structure of ligand binding sites. Although several photoaffinity analogs of propofol exist, ${ }^{8,9}, 12,13$ there is a dearth of propofol probes that also contain a chemical handle to enable subsequent isolation of photolabeled protein, limiting the discovery of novel propofol-interacting proteins. Thus, it is important to expand the library of crosslinkable analogs to provide more tools to understand how propofol and similar molecules, like thymol, carvacrol and zingerone, which are plant phenols with multiple biological activities, interact with their physiological targets.

One of the ideal traits of a photoaffinity probe is structural similarity to the parent molecule. In addition, the choice of crosslinker is important; diazirines have favorable specific activities due to their activation at relatively long wavelengths, the small size of the photoreactive group, and the short half-life of the reactive carbene intermediate. ${ }^{14}$ The rapid quenching of carbenes by reaction with water molecules minimizes unspecific labeling, but also causes low yields of photolabeling. To facilitate the detection and isolation of photolabeled protein, clickable handles such as alkynes provide a convenient post-crosslinking method to incorporate an azidecontaining biotin or fluorescent tag into the photoprobe..$^{15}$ To the best of our knowledge, the only report of a bifunctional propofol analogue has only been demonstrated to retain biological activity for the $\mathrm{GABA}_{\mathrm{A}}$ receptor, ${ }^{8}$ and has not been tested for other targets such as TRPA1 activation.

Although photoactive propofol derivatives do exist, several are unstable,$^{13}$ or have cumbersome synthetic routes, ${ }^{12}$ and only one has a click handle. ${ }^{8}$ We hypothesized that linking the propofol core with a short nonpolar aliphatic spacer to separate the diazirine moiety from the aryl ring would not only preserve the minimal pharmacophore but also facilitate synthetic expediency., ${ }^{9}$ We designed three probes that fulfill these criteria, and we synthesized them using relatively short and efficient synthetic sequences (Schemes 1-3), which could readily be applied to other similar scaffolds. Following synthesis, we used functional assays using calcium influx and binding to a fluorescent indicator as a measure of probe activation of TRPA1 to determine their promise in future crosslinking experiments. 


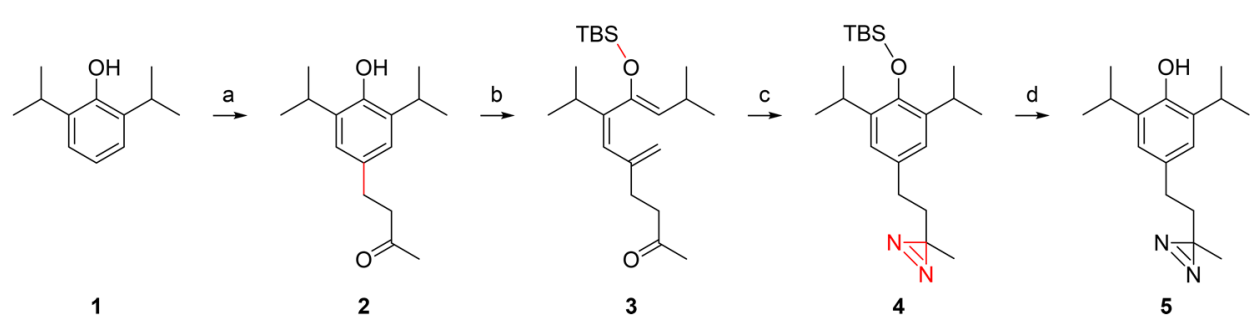

Scheme 1. Synthesis of XPRO

Reagents and conditions: (a) Methyl vinyl ketone, Amberlyst-15, toluene, $50^{\circ} \mathrm{C}, \mathrm{N}_{2}, 6 \mathrm{~h}, 80 \%$; (b) TBSCl, imidazole, DMF, rt, N2, 16 h, 79\%; (c) $\mathrm{NH}_{3}, \mathrm{MeOH}, \mathrm{NH}_{2} \mathrm{OSO}_{3} \mathrm{H},-40^{\circ} \mathrm{C}, \mathrm{N}_{2}, 7$ h; TEA, iodine, $\mathrm{MeOH}, 45 \%$; (d) TBAF-acetic acid, THF, rt, N2, 16 h, 76\%.

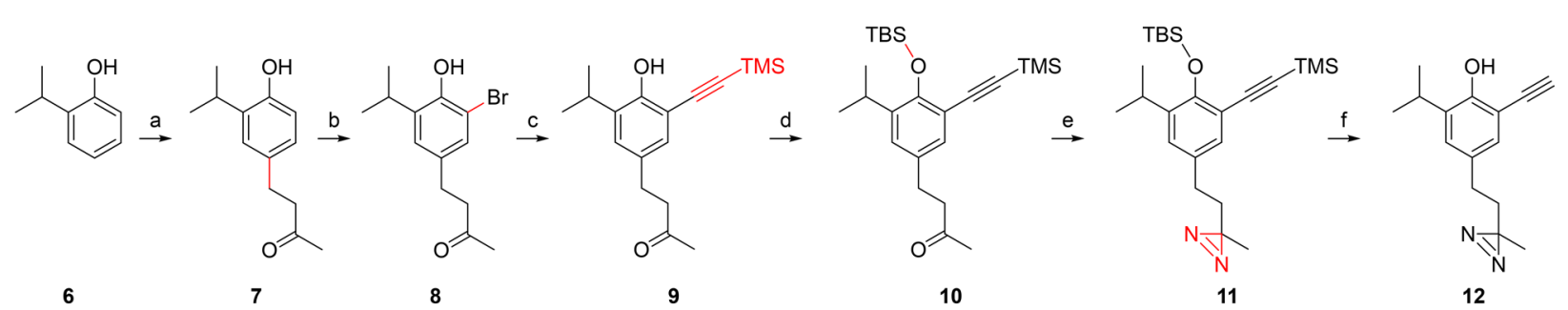

Scheme 2. Synthesis of $o$-XPRO-Click

Reagents and conditions: (a) Methyl vinyl ketone, Amberlyst-15, toluene, $40^{\circ} \mathrm{C}, \mathrm{N}_{2}, 8 \mathrm{~h}, 44 \%$; (b) NBS, DCM, rt, $\mathrm{N}_{2}, 16$ h, 54\%; (c) $\mathrm{PPh}_{3}, \mathrm{PdCl}_{2}(\mathrm{PPh} 3)_{2}$, CuI, ethynyltrimethylsilane, TEA, rt, $\mathrm{N}_{2}, 16$ h, 59\%; (d) TBSCl, imidazole, DMF, rt, $\mathrm{N}_{2}, 16$ h, 82\%; (e) $\mathrm{NH}_{3}, \mathrm{MeOH}, \mathrm{NH}_{2} \mathrm{OSO}_{3} \mathrm{H}$, $40^{\circ} \mathrm{C}, \mathrm{N}_{2}, 7 \mathrm{~h}$; TEA, iodine, $\mathrm{MeOH}, 32 \%$; (f) TBAF-acetic acid, THF, rt, $\mathrm{N}_{2}, 16$ h, 53\%.

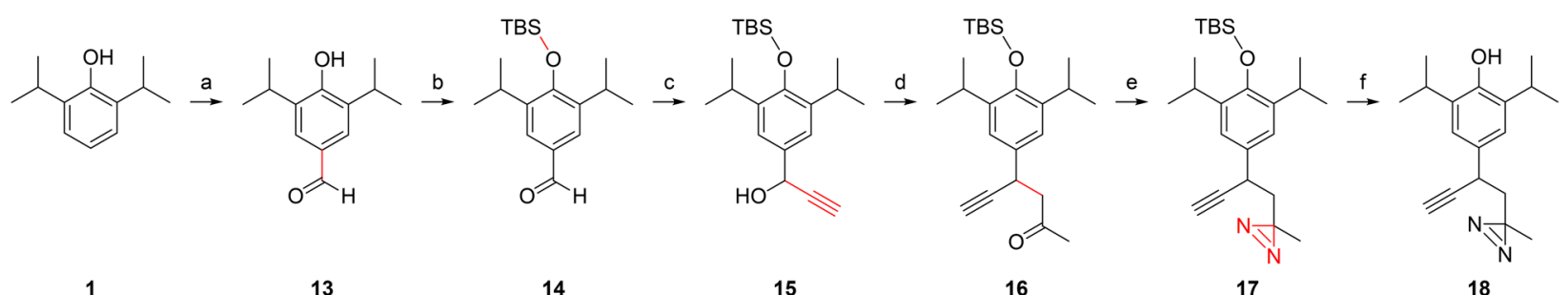

Scheme 3. Synthesis of $p$-XPRO-Click

Reagents and conditions: (a) Hexamethylenetetramine, TFA, HCl, reflux, 9 h, 90\%; (b) TBSCl, imidazole, DCM, rt, $\mathrm{N}_{2}, 16$ h, 63\%; (c) Ethynylmagnesium bromide, THF, $-78^{\circ} \mathrm{C}, \mathrm{N}_{2}, 16 \mathrm{~h}, 83 \%$; (d) cat. $\mathrm{Cp} * \mathrm{RuCl}\left(\mu_{2}-\mathrm{SMe}\right)_{2} \mathrm{RuCP} * \mathrm{Cl}, \mathrm{NHB}_{4} \mathrm{BF}_{4}$, acetone, reflux, $\mathrm{N}_{2}, 5 \mathrm{~h}, 83 \%$; (e) $\mathrm{NH}_{3}, \mathrm{MeOH}_{\text {, }}$ $\mathrm{NH}_{2} \mathrm{OSO}_{3} \mathrm{H},-40^{\circ} \mathrm{C}, \mathrm{N}_{2}, 7 \mathrm{~h}$; TEA, iodine, $\mathrm{MeOH}, 52 \%$; (f) TBAF-acetic acid, THF, rt, $\mathrm{N}_{2}, 16 \mathrm{~h}$, $55 \%$.

We designed our initial crosslinkable probe, XPRO (5), bearing the linker and diazirine moiety in the para position to minimize potential intramolecular interactions of the reactive carbene intermediate while maintaining overall hydrophobicity of the propofol starting point. Indeed, a propofol analog with a trifluoromethyl diazirine directly at the para position was reported to be a poor photolabel. ${ }^{9}{ }^{13}$ Synthesis of XPRO was achieved in an expedient 5-step sequence (Scheme 1). Initial functionalization of the para-position was achieved through an Amberlyst-15-mediated alkylation $^{16}$ followed by protection of the phenol hydroxyl as a TBS silyl ether. The pendant methyl ketone was subsequently converted to the requisite diazirine via a two-step sequence. ${ }^{17,18}$ Lastly, deprotection of the TBS ether with TBAF afforded XPRO. Overall yield for this sequence was $22 \%$. 
We next sought to generate an analog with a clickable group to enable potential labeling studies. We envisioned placing an alkyne at two possible locations within XPRO - in one analog one of the two isopropyl groups could be substituted with an alkyne (o-XPRO-Click) and in a second analog the alkyne could be appended proximal to the diazirine itself ( $p$-XPRO-Click). At the outset, we chose to synthesize and profile both designs, since it was unclear which would have the best potency/reactivity profile.

To synthesize $o$-XPRO-Click (12; Scheme 2) starting from 2-isopropylphenol (6), Amberlyst-15 was again used to generate the alkyl ketone 7. Subsequent bromination with NBS, Sonogashira coupling with TMS-acetylene, and phenol protection yielded the bis-silyl-protected intermediate 10. Functionalization of the ketone using previously established conditions, followed by deprotection, generated $o$-XPRO-Click. In the case of $p$-XPRO-Click (18; Scheme 3), Duff formylation generated a benzaldehyde intermediate which, after phenol protection, was subjected to a Grignard reaction with ethynylmagnesium bromide. Subsequent propargylic alkylation ${ }^{19}$ followed by diazirination and deprotection yielded $p$-XPRO-Click. Moreover, $o$-XPRO-Click and $p$-XPRO-conjugation experiments with 3-Azido-7-hydroxycoumarin, whose fluorescence increases upon a successful click reaction with an alkyne, ${ }^{20}$ demonstrate their ability to react with azide partners (Supplementary figure 1).

As a first assessment of the biological activity of our three new photocrosslinkable propofol analogs, we tested their ability to activate TRPA1, leveraging our previously developed cellbased calcium-influx assay. ${ }^{6}$ For TRPA1 production, we chose baculovirus-infected insect cells, a common heterologous expression system for eukaryotic integral membrane proteins. ${ }^{21}$ Cells were loaded with Fura-2, a calcium-sensitive ratiometric fluorescent dye. Ligand binding and activation causes ion channels like TRPA1 to open, allowing calcium to flow into cells and bind Fura-2, resulting in an absorption shift. ${ }^{22}$

After measuring background fluorescence levels, addition of $60 \mu \mathrm{M}$ XPRO or propofol at $60 \mathrm{~s}$ elicited a rise in $\left[\mathrm{Ca}^{2+}\right]_{\mathrm{i}}$ in TRPA1-expressing cells, resulting in an increase in the 340/380 ratio of the Fura-2 dye (Figure 1A). Expression of TRPA1 in all samples was confirmed by activation at $180 \mathrm{~s}$ with $1 \mathrm{mM}$ AITC, an electrophilic TRPA1 agonist. ${ }^{23,}{ }^{24}$ Interestingly, $o$-XPRO-Click was a weaker TRPA1 agonist than propofol (Figure 1B). We hypothesize that the potency difference was due to replacement of a key structural feature of propofol, one of the 2-isopropyl group, with a smaller and non-branched alkyne. Consistent with this hypothesis, $p$-XPRO-Click, which preserves both 2-isopropyl substituents, was at least as efficient as propofol (Figure 1C).

To rule out nonspecific calcium influx due to increased hydrophobicity of XPRO relative to propofol, we also tested activation of TRPV1, a related channel found on TRPA1-expressing sensory nerves and crucial for pain sensation. ${ }^{25}$ As expected, ${ }^{26}$ neither propofol nor XPRO activated TRPV1 while capsaicin, which serves as a positive control for functional TRPV1 expression, was a potent TRPV1 agonist (Figure 1D). In addition, neither $o$-XPRO-Click nor $p$ XPRO-Click elicited calcium influx in TRPV1-expressing cells (Figures 1E and 1F). Taken together, calcium-influx assays demonstrate that XPRO, $o$-XPRO-Click, and $p$-XPRO-Click share similar TRPA1 potency with propofol. 

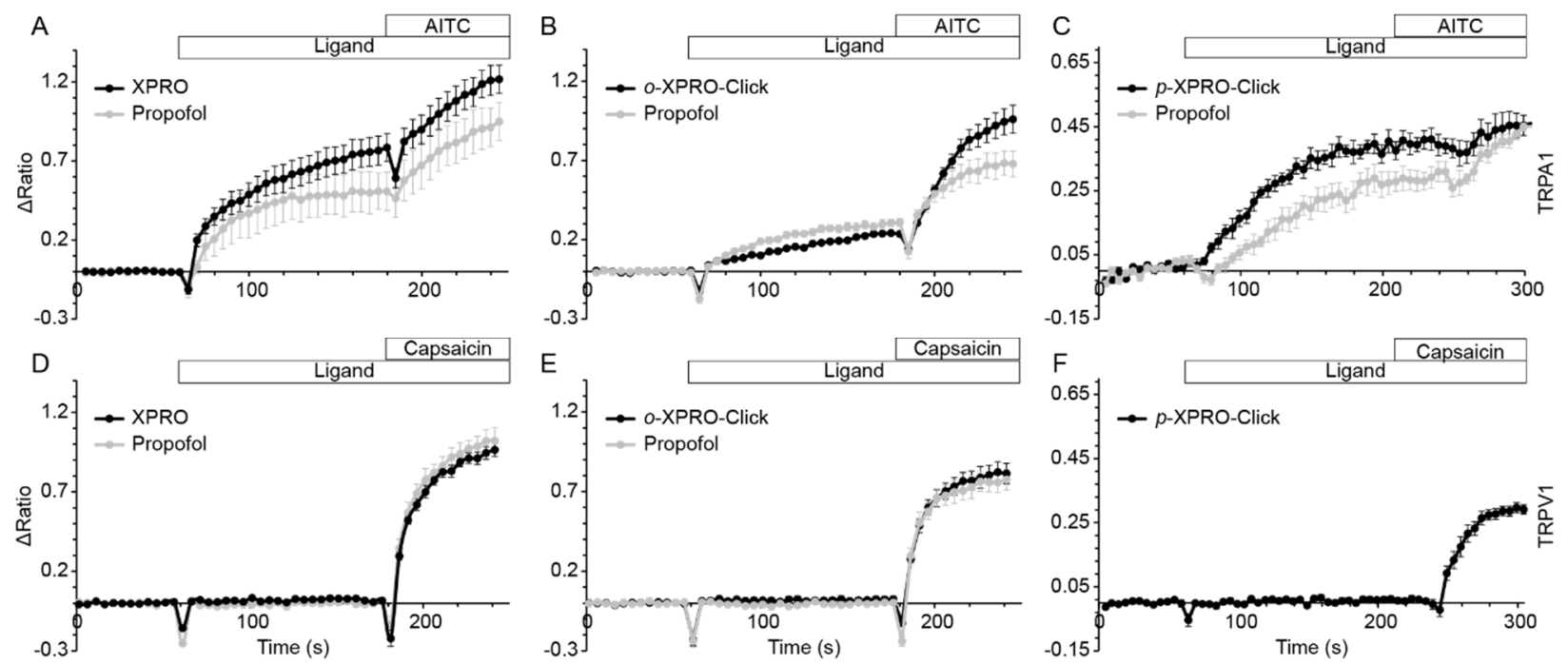

Figure 1. XPRO, $o$-XRO-Click, and $p$-XPRO-Click and propofol elicit calcium influx in Sf21 insect cells heterologously expressing TRPA1 but not TRPV1. (A, B, C) Time traces showing the net change in Fura-2 340/380 fluorescence ratio ( $\triangle$ Ratio) in TRPA1-expressing insect cells. Adding XPRO (A), o-XPRO-Click (B) or $p$-XPRO-Click (C) at $60 \mathrm{~s}$ caused a rise in $\left[\mathrm{Ca}^{2+}\right]_{\mathrm{i}}$. Traces showing activation of the equivalent batches of cells with $60 \mu \mathrm{M}$ propofol (grey traces) are included as positive controls in each panel. Addition of $1 \mathrm{mM}$ allyl isothiocyanate (AITC) at $180 \mathrm{~s}$ provided a positive control for mouse TRPA1 expression. Data represent mean $\pm \mathrm{SEM}$ (n=4-14). (D, E, F) Addition of $60 \mu \mathrm{M}$ XPRO (D), $o$-XPRO-Click (E) or $p$-XPRO-Click (F) or propofol (grey traces) at $60 \mathrm{~s}$ did not cause a rise in $\left[\mathrm{Ca}^{2+}\right]_{\mathrm{i}}$ in rat TRPV1-expressing insect cells. Addition of $75 \mathrm{nM}$ capsaicin, a TRPV1-specific agonist, at $180 \mathrm{~s}$ did elicit a rise in $\left[\mathrm{Ca}^{2+}\right] \mathrm{i}$, confirming TRPV1 expression in all samples. Data represent mean \pm SEM for $n=3-12$.

In summary, the structure-function studies highlight promising photoactivatable propofol analogs to move forward in crosslinking experiments. The synthetic strategies described here are also applicable to alkyl phenols like propofol, such as carvacrol and thymol, and molecules that contain an analogous linker in the para position, such as zingerone, all of which include TRPA1 modulation among their biological activities. ${ }^{27}$ Thus, the combination of the diazirine and alkyne functionality enables not only detection and enrichment of photolabeled biological targets but also interrogation of the propofol-interacting proteome and generation of novel ion channel modulators through click chemistry reactions.

\section{Acknowledgments}

We thank members of the Gaudet and Kahne lab for insightful discussions and technical assistance. Financial support for this work was provided by the American Heart Association (16GRNT27250119). K.A.S. was supported by an NSF Graduate Research Fellowship (DGE1144152) and a Ford Foundation Fellowship.

\section{Declaration of Interest}

None.

\section{Supplementary Data}

${ }^{1} \mathrm{H}$ and ${ }^{13} \mathrm{C}$ NMR spectra with synthesis methods. 


\section{References}

1. Jalota L, Kalira V, George E, et al. Prevention of pain on injection of propofol: systematic review and meta-analysis. BMJ. 2011;342: d1110. 10.1136/bmj.d1110

2. Picard P, Tramer MR. Prevention of pain on injection with propofol: a quantitative systematic review. Anesth Analg. 2000;90(4): 963-969. 10.1097/00000539-200004000-00035

3. Jurd R, Arras M, Lambert S, et al. General anesthetic actions in vivo strongly attenuated by a point mutation in the GABA(A) receptor beta3 subunit. FASEB J. 2003;17(2): 250-252. 10.1096/fj.02-0611fje

4. Matta JA, Cornett PM, Miyares RL, Abe K, Sahibzada N, Ahern GP. General anesthetics activate a nociceptive ion channel to enhance pain and inflammation. Proc Natl Acad Sci U S A. 2008;105(25): 8784-8789. 10.1073/pnas.0711038105

5. Ton HT, Phan TX, Ahern GP. Inhibition of Ligand-Gated TRPA1 by General Anesthetics. Mol Pharmacol. 2020;98(3): 185-191. 10.1124/mol.119.118851

6. Woll KA, Skinner KA, Gianti E, et al. Sites Contributing to TRPA1 Activation by the Anesthetic Propofol Identified by Photoaffinity Labeling. Biophys J. 2017;113(10): 2168-2172. 10.1016/j.bpj.2017.08.040

7. Ton HT, Phan TX, Abramyan AM, Shi L, Ahern GP. Identification of a putative binding site critical for general anesthetic activation of TRPA1. Proc Natl Acad Sci U S A. 2017;114(14): 3762-3767. 10.1073/pnas.1618144114

8. Woll KA, Murlidaran S, Pinch BJ, et al. A Novel Bifunctional Alkylphenol Anesthetic Allows Characterization of gamma-Aminobutyric Acid, Type A (GABAA), Receptor Subunit Binding Selectivity in Synaptosomes. $J$ Biol Chem. 2016;291(39): 20473-20486. 10.1074/jbc.M116.736975

9. Yip GM, Chen ZW, Edge CJ, et al. A propofol binding site on mammalian GABAA receptors identified by photolabeling. Nat Chem Biol. 2013;9(11): 715-720. $10.1038 /$ nchembio. 1340

10. Hill JR, Robertson AAB. Fishing for Drug Targets: A Focus on Diazirine Photoaffinity Probe Synthesis. J Med Chem. 2018;61(16): 6945-6963. 10.1021/acs.jmedchem.7b01561

11. Prevet H, Collins I. Labelled chemical probes for demonstrating direct target engagement in living systems. Future Med Chem. 2019;11(10): 1195-1224. 10.4155/fmc-2018-0370

12. Hall MA, Xi J, Lor C, et al. m-Azipropofol (AziPm) a photoactive analogue of the intravenous general anesthetic propofol. $J$ Med Chem. 2010;53(15): 5667-5675. 10.1021/jm1004072

13. Stewart DS, Savechenkov PY, Dostalova Z, et al. p-(4-Azipentyl)propofol: a potent photoreactive general anesthetic derivative of propofol. J Med Chem. 2011;54(23): 8124-8135. 10.1021/jm200943f

14. Dubinsky L, Krom BP, Meijler MM. Diazirine based photoaffinity labeling. Bioorg Med Chem. 2012;20(2): 554-570. 10.1016/j.bmc.2011.06.066

15. Li Z, Hao P, Li L, et al. Design and synthesis of minimalist terminal alkyne-containing diazirine photo-crosslinkers and their incorporation into kinase inhibitors for cell- and tissuebased proteome profiling. Angew Chem Int Ed Engl. 2013;52(33): 8551-8556. 10.1002/anie.201300683

16. Bunce RA, Reeves HD. Amberlyst-15 catalyzed addition of phenols to $\alpha, \beta$-unsaturated ketones. Synthetic Communications 1989;19(5-6): 1109-1117.

17. Church RFR, Kende AS, Weiss MJ. Diazirines. I. Some Observations on the Scope of the Ammonia-Hydroxylamine-O-sulfonic Acid Diaziridine Synthesis. The Preparation of Certain 
Steroid Diaziridines and Diazirines. Journal of the American Chemical Society. 1965;87(12): 2665-2671. 10.1021/ja01090a025

18. Church RFR, Weiss MJ. Diazirines. II. Synthesis and properties of small functionalized diazirine molecules. Observations on the reaction of a diaziridine with the iodine-iodide ion system. The Journal of Organic Chemistry. 1970;35(8): 2465-2471. 10.1021/jo00833a001

19. Nishibayashi Y, Wakiji I, Ishii Y, Uemura S, Hidai M. Ruthenium-catalyzed propargylic alkylation of propargylic alcohols with ketones: straightforward synthesis of gamma-keto acetylenes. J Am Chem Soc. 2001;123(14): 3393-3394. 10.1021/ja015670z

20. Sivakumar K, Xie F, Cash BM, Long S, Barnhill HN, Wang Q. A Fluorogenic 1,3Dipolar Cycloaddition Reaction of 3-Azidocoumarins and Acetylenes. Organic Letters. 2004;6(24): 4603-4606. 10.1021/o1047955x

21. He Y, Wang K, Yan N. The recombinant expression systems for structure determination of eukaryotic membrane proteins. Protein Cell. 2014;5(9): 658-672. 10.1007/s13238-014-0086-4 22. Grynkiewicz G, Poenie M, Tsien RY. A new generation of $\mathrm{Ca} 2+$ indicators with greatly improved fluorescence properties. J Biol Chem. 1985;260(6): 3440-3450.

23. Hinman A, Chuang HH, Bautista DM, Julius D. TRP channel activation by reversible covalent modification. Proc Natl Acad Sci U S A. 2006;103(51): 19564-19568. 10.1073/pnas.0609598103

24. Macpherson LJ, Dubin AE, Evans MJ, et al. Noxious compounds activate TRPA1 ion channels through covalent modification of cysteines. Nature. 2007;445(7127): 541-545. 10.1038 /nature 05544

25. Fernandes ES, Fernandes MA, Keeble JE. The functions of TRPA1 and TRPV1: moving away from sensory nerves. $B r \quad J$ Pharmacol. 2012;166(2): 510-521. 10.1111/j.14765381.2012.01851.x

26. Nishimoto R, Kashio M, Tominaga M. Propofol-induced pain sensation involves multiple mechanisms in sensory neurons. Pflugers Arch. 2015;467(9): 2011-2020. 10.1007/s00424-014$1620-1$

27. Lee SP, Buber MT, Yang Q, et al. Thymol and related alkyl phenols activate the hTRPA1 channel. Br J Pharmacol. 2008;153(8): 1739-1749. 10.1038/bjp.2008.85 


\section{Supplementary Information}

\section{Efficient and flexible synthesis of new photoactivatable propofol analogs}

Kenneth A. Skinner ${ }^{a, b}$, Joseph S. Wzorek ${ }^{c, d}$, Daniel Kahne ${ }^{a, d}$ and Rachelle Gaudet ${ }^{a, *}$

a Department of Molecular and Cellular Biology, Harvard University, Cambridge, MA 02138, USA.

b Present address: Departments of Medicine and Pharmacology, University of California, San Diego, La Jolla 92161, USA.

c Present address: Novartis Institutes for BioMedical Research, Cambridge, MA 02139, USA.

d Department of Chemistry and Chemical Biology, Harvard University, Cambridge, MA 02138, USA.

S2. UV and fluorescence characterization of diazirine and click groups

S3-10. General synthetic procedures

S11-42. ${ }^{1} \mathrm{H}$ and ${ }^{13} \mathrm{C}$ NMR spectra 


\section{XPRO absorbance spectrum}

UV spectrum data was acquired at a 10-nm wavelength step on a Flexstation 3 Plate Reader (Molecular Devices; Sunnyvale, CA).

\section{Click reaction with o-XPRO-Click and 3-Azido-7-hydroxycoumarin}

$0.5 \mathrm{mM}$ o-XPRO-Click was mixed with $1 \mathrm{mM}$ 3-Azido-7-hydroxycoumarin in $100 \mathrm{mM}$ phosphate buffer, $\mathrm{pH} 7.5$ and $150 \mathrm{mM} \mathrm{NaCl}$. A premixed solution of $0.1 \mathrm{mM} \mathrm{CuSO}_{4}$ and $0.5 \mathrm{mM}$ Tris(benzyltriazolylmethyl)amine (TBTA) was added, followed by addition of 5 $\mathrm{mM}$ sodium ascorbate. The reaction proceeded at $37^{\circ} \mathrm{C}$ for 1 hour and the sample was excited at $404 \mathrm{~nm}$ while emission was measured with a SpectraMax i3 plate reader (Sunnyvale, CA).

\section{Click reaction with $p$-XPRO-Click and 3-Azido-7-hydroxycoumarin}

$0.5 \mathrm{mM} p$-XPRO-Click was mixed with 0-3 mM 3-Azido-7-hydroxycoumarin in phosphatebuffered saline. A premixed solution of $0.1 \mathrm{mM} \mathrm{CuSO}_{4}$ and $0.5 \mathrm{mM}$ TBTA was added, followed by addition of $5 \mathrm{mM}$ sodium ascorbate. The reaction proceeded at $37^{\circ} \mathrm{C}$ for 1 hour and the sample was excited at $404 \mathrm{~nm}$ and emission at $480 \mathrm{~nm}$ was measured with increasing concentration of 3-Azido-7-hydroxycoumarin using a SpectraMax i3 plate reader (Sunnyvale, CA).

A
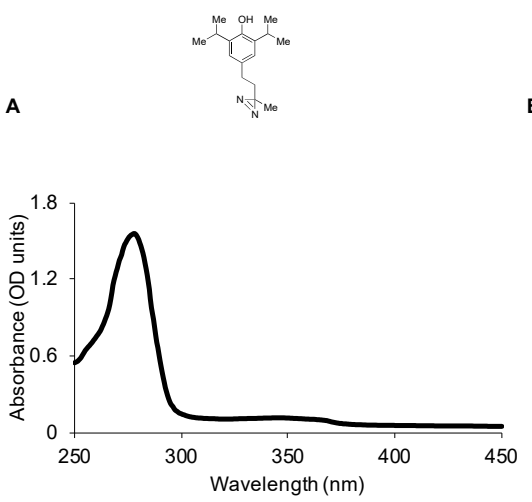

B
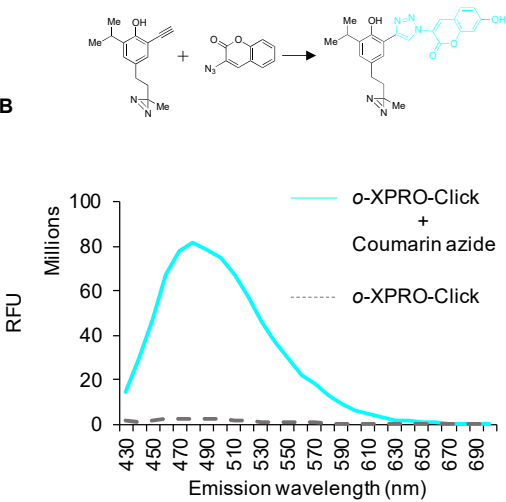

c
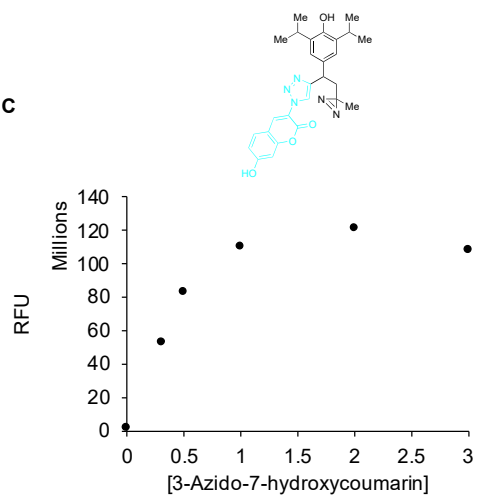

Supplementary figure 1. Characterization of diazirine and click handle of synthesized probes. (A) UV absorption spectrum of XPRO $\left(0.2 \mathrm{mg} \mathrm{mL}^{-1}\right)$ in methanol showing absorbance of aromatic region and an absorption band between 320-360 $\mathrm{nm}$ due to the diazirine group (B) o-XPRO-Click conjugates with coumarin azide whose fluorescence increases upon successful click reaction (404 $\mathrm{nm}$ excitation). Solid cyan line indicates $o$-XPRO-Click incubated with coumarin azide under copper-catalyzed conditions. Dashed line indicates $o$-XPRO-Click incubated without coumarin azide under same conditions. Background 3-Azido-7-hydroxycoumarin was subtracted from all values (C) $0.5 \mathrm{mM} p$-XPRO-Click (0.5 mM) reacts with coumarin azide resulting in a fluorescence increase upon click reaction. 


\section{General synthetic procedures}

Hexamethylenetetramine was purchased from TCl America (Portland, OR). Ruthenium Dichlorobis( $\mu$-methanethioato)bis(pentamethylcyclopentadienyl)diruthenium(III) was purchased from Strem Pharmaceuticals (Newburyport, MA). All other chemicals were purchased from Sigma-Aldrich. Chemicals were used as received from commercial vendors unless otherwise noted. Crude products were chromatographed on a Teledyne Isco CombiFlash system using the indicated solvents (Lincoln, NE). ${ }^{1} \mathrm{H}$ and ${ }^{13} \mathrm{C}$ nuclear magnetic resonance (NMR) spectra were recorded on an Inova $500 \mathrm{MHz}$ nuclear spectrometer in the Harvard Chemistry \& Chemical Biology (CCB) facility. Mass spectra of synthesized compounds were acquired on an Agilent 6220 LC-TOF (Santa Clara, CA) in the Harvard Bauer Core.

Preparation of XPRO (5)

\section{4-(4-Hydroxy-3,5-diisopropylphenyl)butan-2-one (2)}

A similar procedure was adapted with minor modifications from Bunce et al. ${ }^{16}$ To a $5-\mathrm{mL}$ toluene solution of 2,6-diisopropylphenol $(2.83 \mathrm{~mL}, 15.3 \mathrm{mmol}) 1$ in a round-bottomed flask under an atmosphere of nitrogen was added $326 \mathrm{mg}$ of Amberlyst-15. The slurry was stirred at room temperature while a $1-\mathrm{mL}$ toluene solution of methyl vinyl ketone $(0.415 \mathrm{~mL}, 5.1 \mathrm{mmol})$ was added dropwise. The vessel was heated to $50^{\circ} \mathrm{C}$ and allowed to proceed for 6 hours, upon which the reaction was partitioned between water and ether. The ether solution was washed with water, brine, dried over $\mathrm{Na}_{2} \mathrm{SO}_{4}$ and concentrated in vacuo. The residue was purified using a Teledyne Isco CombiFlash system and the product eluted at $100 \%$ DCM in hexanes. The appropriate fractions were combined and concentrated to yield $1 \mathrm{~g}(80 \%)$ of the title compound $\mathbf{2}$.

${ }^{1} \mathrm{H}$ NMR $\left(500 \mathrm{MHz}, \mathrm{CDCl}_{3}\right): \delta 6.88$ (s, 2H, Harom), 4.69 (s, 1H, ArOH), 3.15 (sept, $2 \mathrm{H}$, $\mathrm{J}=6.9 \mathrm{~Hz}, \mathrm{CH}-\mathrm{i}-\mathrm{Pr}), 2.88-2.79\left(\mathrm{~m}, 2 \mathrm{H}, \mathrm{CH}_{2}\right), 2.79-2.71\left(\mathrm{~m}, 2 \mathrm{H}, \mathrm{CH}_{2}\right), 2.16\left(\mathrm{~s}, 3 \mathrm{H}, \mathrm{H}_{3} \mathrm{C}-\right.$ $\mathrm{C}=\mathrm{O}), 1.27\left(\mathrm{~d}, 12 \mathrm{H}, \mathrm{J}=6.9 \mathrm{~Hz}, \mathrm{H}_{3} \mathrm{C}-\mathrm{i}-\mathrm{Pr}\right)$.

${ }^{13} \mathrm{C}$ NMR $\left(125 \mathrm{MHz}, \mathrm{CDCl}_{3}\right): \delta 208.7(\mathrm{C}=\mathrm{O}), 148.3,133.8,132.7,123.2\left(\mathrm{CH}_{\text {arom }}\right), 45.8$, $30.1,29.7,27.2,22.8$.

HRMS calc'd for $\mathrm{C}_{16} \mathrm{H}_{24} \mathrm{O}_{2}:[\mathrm{M}+\mathrm{H}]$ 249.1855. Found: 249.1842 .

\section{4-[4-(tert-Butyldimethylsilyloxy)-3,5-diisopropylphenyl]butan-2-one (3)}

Dimethylformamide (DMF; $1.7 \mathrm{~mL}$ ) was added to $385 \mathrm{mg}$ of $2(1.55 \mathrm{mmol}, 1.0 \mathrm{eq})$ with stirring at room temperature in a round bottomed flask, followed by addition of $369 \mathrm{mg}$ of imidazole $(5.425 \mathrm{mmol}, 3.5 \mathrm{eq})$. Next, $701 \mathrm{mg}$ of tert-butyldimethylsilyl chloride (TBSCl; $4.65 \mathrm{mmol}, 3.0 \mathrm{eq}$ ) was added under an atmosphere of nitrogen. After stirring at room temperature overnight, the reaction was partitioned between hexanes and water. The organic layer was washed with water and saturated $\mathrm{NaHCO}_{3}$, dried over $\mathrm{Na}_{2} \mathrm{SO}_{4}$, and concentrated in vacuo. Following chromatography using a Teledyne Isco CombiFlash 
system (15\% ethyl acetate in hexanes as eluent), the appropriate fractions were combined and concentrated to yield $446 \mathrm{mg}(79 \%)$ of $\mathbf{3}$ as an orange oil.

${ }^{1} \mathrm{H} \mathrm{NMR}\left(500 \mathrm{MHz}, \mathrm{CDCl}_{3}\right): \delta 6.85$ (s, $2 \mathrm{H}, \mathrm{H}_{\text {arom }}$ ), 3.28 (sept, $2 \mathrm{H}, \mathrm{J}=6.8 \mathrm{~Hz}, \mathrm{CH}-\mathrm{i}-\mathrm{Pr}$ ), $2.87-$ $2.79\left(\mathrm{~m}, 2 \mathrm{H}, \mathrm{CH}_{2}\right), 2.79-2.71\left(\mathrm{~m}, 2 \mathrm{H}, \mathrm{CH}_{2}\right), 2.16\left(\mathrm{~s}, 3 \mathrm{H}, \mathrm{H}_{3} \mathrm{C}-\mathrm{C}=\mathrm{O}\right), 1.16(\mathrm{~d}, 12 \mathrm{H}, \mathrm{J}=6.8$ $\mathrm{Hz}, \mathrm{H}_{3} \mathrm{C}-\mathrm{i}-\mathrm{Pr}$ ), 1.03 (s, 9H, tert-butyl), 0.18 (s, 6H, Si-CH$)_{3}$.

${ }^{13} \mathrm{C}$ NMR (125 MHz, $\left.\mathrm{CDCl}_{3}\right): \delta 208.7(\mathrm{C}=\mathrm{O}), 147.4,139.0,133.7,123.1$ ( $\left.\mathrm{CH}_{\text {arom }}\right), 45.7$, $30.1,29.8,26.5,26.1,23.4,18.9,-3.3\left(\mathrm{H}_{3} \mathrm{C}-\mathrm{Si}\right)$.

HRMS calc'd for $\mathrm{C}_{22} \mathrm{H}_{38} \mathrm{O}_{2} \mathrm{Si}$ : [M + H] 363.2719. Found: 363.2719.

\section{3-[4-(tert-Butyldimethylsilyl)oxy)-3,5-diisopropylphenyl]-3-methyl-3H-diazirine (4)}

Under an atmosphere of nitrogen, $446 \mathrm{mg}$ of $3(1.23 \mathrm{mmol}, 1.0 \mathrm{eq})$ was dissolved in a mixture of methanol $(\mathrm{MeOH})$-ether $(1: 1,4.5 \mathrm{~mL})$ and cooled to $-40^{\circ} \mathrm{C}$. A solution of $2.0 \mathrm{M}$ $\mathrm{NH}_{3}$ in $\mathrm{MeOH}(31 \mathrm{~mL})$ was added dropwise with stirring. The reaction was allowed to proceed for 6 hours at $-40^{\circ} \mathrm{C}$. A solution of hydroxylamine-O-sulfononic acid $\left(\mathrm{NH}_{2} \mathrm{OSO}_{3} \mathrm{H}\right.$; $208 \mathrm{mg}, 1.845 \mathrm{mmol}, 1.5 \mathrm{eq}$ ) in $3.6 \mathrm{~mL}$ of methanol was added dropwise. After 1 hour, the flask was kept at $-20^{\circ} \mathrm{C}$ for 3 days with occasional stirring. After completion, the mixture was filtered, dried with $\mathrm{Na}_{2} \mathrm{SO}_{4}$, concentrated in vacuo. The crude material was dissolved in a mixture of methanol $(18 \mathrm{~mL})$ and $0.515 \mathrm{~mL}$ of triethylamine (TEA; 3.69 $\mathrm{mmol}, 3.0 \mathrm{eq}$ ), and cooled to $-10^{\circ} \mathrm{C}$. A solution of iodine ( $\left.\mathrm{I}_{2} ; 312 \mathrm{mg}, 1.23 \mathrm{mmol}, 1.0 \mathrm{eq}\right)$ in DCM $(9 \mathrm{~mL})$ was added dropwise while stirring. Once the solution remained persistently brown in color, the excess iodine was quenched with a $5 \%$ solution of $\mathrm{Na}_{2} \mathrm{~S}_{2} \mathrm{O}_{3}(4.5 \mathrm{~mL})$, which turned the reaction orange. The mixture was diluted with water and extracted with ether. The combined organic phases were washed with water and dried over $\mathrm{Na}_{2} \mathrm{SO}_{4}$. Concentration and chromatography using a Teledyne Isco CombiFlash system (3\% ethyl acetate in hexanes as eluent) yielded $205 \mathrm{mg} \mathrm{(45 \% )}$ of diazirine 4 as an orange oil.

${ }^{1} \mathrm{H}$ NMR $\left(500 \mathrm{MHz}, \mathrm{CDCl}_{3}\right): \delta 6.83$ (s, 2H, Harom), 3.28 (sept, 2H, J=6.9 Hz, HC-i-Pr), 2.43 (m, 2H, $\left.\mathrm{CH}_{2}\right), 1.65\left(\mathrm{~m}, 2 \mathrm{H}, \mathrm{CH}_{2}\right), 1.16\left(\mathrm{~d}, 12 \mathrm{H}, \mathrm{J}=6.9 \mathrm{~Hz}, \mathrm{H}_{3} \mathrm{C}-\mathrm{i}-\mathrm{Pr}\right), 1.03(\mathrm{~s}, 9 \mathrm{H}$, tert-butyl), $1.00\left(\mathrm{~s}, 3 \mathrm{H}, \mathrm{a}-\mathrm{azi}-\mathrm{CH}_{3}\right) 0.18\left(\mathrm{~s}, 6 \mathrm{H}, \mathrm{Si}-\mathrm{CH}_{3}\right)$.

${ }^{13} \mathrm{C}$ NMR (125 MHz, $\left.\mathrm{CDCl}_{3}\right): \delta$ 147.3, 139.0, 133.6, 123.1 ( $\left.\mathrm{CH}_{\text {arom }}\right), 36.7,29.8,26.5,26.1$, $25.7,23.4,19.9,18.8,-3.3\left(\mathrm{H}_{3} \mathrm{C}-\mathrm{Si}\right)$.

HRMS calc'd for $\mathrm{C}_{22} \mathrm{H}_{39} \mathrm{~N}_{2} \mathrm{OSS}:[\mathrm{M}+\mathrm{H}]$ 375.2832. Found: 375.2841 .

\section{2,6-Diisopropyl-4-[2-(3-methyl-3H-diazirin-3-yl)ethyl]phenol (5)}

Under an atmosphere of nitrogen, $32 \mathrm{mg}$ of $4(0.0855 \mathrm{mmol}, 1.0 \mathrm{eq})$ was deprotected with dropwise addition of tetra-n-butylammonium fluoride (TBAF)-acetic acid (1:2 molar ratio, $1 \mathrm{M} \mathrm{TBAF}$ in tetrahydrofuran + neat acetic acid, $0.43 \mathrm{~mL}$ ) on ice and the reaction was 
allowed to warm to room temperature overnight to obtain crude product. The mixture was diluted with water and the aqueous layer was extracted with ethyl acetate. The combined organic phases were purified using a Teledyne Isco CombiFlash system (5\% ethyl acetate in hexanes as eluent) yielding $17 \mathrm{mg}(76 \%)$ of $\mathbf{5}$ as an orange oil after concentration.

${ }^{1} \mathrm{H}$ NMR $\left(500 \mathrm{MHz}, \mathrm{CDCl}_{3}\right): \delta 6.84$ (s, 2H, Harom), 4.66 (s, $\left.1 \mathrm{H}, \mathrm{ArOH}\right), 3.14$ (sept, $2 \mathrm{H}$, J=6.9 Hz, HC-i-Pr), $2.43\left(\mathrm{~m}, 2 \mathrm{H}, \mathrm{CH}_{2}\right), 1.65\left(\mathrm{~m}, 2 \mathrm{H}, \mathrm{CH}_{2}\right), 1.27$ (d, 12H, J=6.9 Hz, H3 $\mathrm{C}-\mathrm{i}-$ $\mathrm{Pr}), 1.03$ (s, 3H, a-azi-CH3).

${ }^{13} \mathrm{C}$ NMR (125 MHz, $\left.\mathrm{CDCl}_{3}\right): \delta$ 148.2, 133.7, 132.6, 123.2 ( $\left.\mathrm{CH}_{\text {arom }}\right), 36.9,29.9,27.2,25.9$, 22.8, 20.0.

HRMS: $m / z$ calc'd for $\mathrm{C}_{16} \mathrm{H}_{24} \mathrm{~N}_{2} \mathrm{O}:[\mathrm{M}+\mathrm{H}]$ 261.1967. Found: 261.1964 .

Preparation of o-XPRO-Click (12)

\section{4-(4-hydroxy-3-isopropylphenyl)butan-2-one (7)}

Under an atmosphere of nitrogen, $3 \mathrm{~mL}$ of 2-isopropylphenol $(22.3 \mathrm{mmol}, 3.0 \mathrm{eq}) 6$ and $3 \mathrm{~mL}$ of toluene were stirred in an ice-cold round-bottomed flask. Then, Amberlyst-15 (475 $\mathrm{mg}$ ) was added. Methyl vinyl ketone $(0.45 \mathrm{~mL}, 7.43 \mathrm{mmol}, 1.0 \mathrm{eq})$ in $2 \mathrm{~mL}$ of toluene was added dropwise. The reaction was warmed to $40^{\circ} \mathrm{C}$ for 8 hours, then partitioned between ether and water. The ether solution was washed with water, brine, dried over $\mathrm{Na}_{2} \mathrm{SO}_{4}$ and concentrated under vacuum. The crude material was purified using a Teledyne Isco CombiFlash system (30\% ethyl acetate in hexanes as eluent) yielding $2 \mathrm{~g}(44 \%)$ of $7 \mathrm{a}$ pale-yellow oil.

${ }^{1} \mathrm{H}$ NMR $\left(500 \mathrm{MHz}, \mathrm{CDCl}_{3}\right): \delta 7.01(\mathrm{~s}, 1 \mathrm{H}), 6.88(\mathrm{dd}, J=8.1,2.3 \mathrm{~Hz}, 1 \mathrm{H}), 6.68(\mathrm{~d}, J=8.0$ $\mathrm{Hz}, 1 \mathrm{H}$ ), 4.77 (bs, 1H), 3.20 (sept, J = 7.0 Hz, 1H), 2.94- $2.80(\mathrm{~m}, 2 \mathrm{H}), 2.80-2.68(\mathrm{~m}$, $2 \mathrm{H}), 2.16(\mathrm{~s}, 3 \mathrm{H}), 1.26(\mathrm{~d}, J=6.9 \mathrm{~Hz}, 6 \mathrm{H})$

${ }^{13} \mathrm{C}$ NMR: $\left(125 \mathrm{MHz}, \mathrm{CDCl}_{3}\right): \delta 208.8,151.2,134.5,133.1,126.3,126.2,115.3,110,45.7$, $30.1,29.3,27,22.6$

HRMS calc'd for $\mathrm{C}_{13} \mathrm{H}_{20} \mathrm{O}_{2}:[\mathrm{M}+\mathrm{Na}]$ 229.1204. Found: 229.1222

\section{4-(3-bromo-4-hydroxy-5-isopropylphenyl)butan-2-one (8)}

Under an atmosphere of nitrogen, $393 \mathrm{mg}$ of $7(1.905 \mathrm{mmol}, 1.0 \mathrm{eq})$ was stirred in DCM (12 mL). $373 \mathrm{mg}$ of N-bromosuccinimide (NBS; $2.1 \mathrm{mmol}, 1.1 \mathrm{eq}$ ) was dissolved in 1.4 $\mathrm{mL}$ DMF and added dropwise to the mixture. The reaction proceeded overnight at room temperature. The mixture was then diluted with DCM, washed with water, dried over $\mathrm{Na}_{2} \mathrm{SO}_{4}$, and concentrated in vacuo. The crude material was purified using a Teledyne 
Isco CombiFlash system (15\% ethyl acetate in hexanes as eluent) yielded $300 \mathrm{mg} \mathrm{(54 \% )}$ of 8 as a pale-yellow oil.

${ }^{1} \mathrm{H}$ NMR $\left(500 \mathrm{MHz}, \mathrm{CDCl}_{3}\right): \delta 7.14(\mathrm{~s}, 1 \mathrm{H}), 6.96(\mathrm{dd}, J=8.1,2.3 \mathrm{~Hz}, 1 \mathrm{H}), 6.68(\mathrm{~d}, J=8.0$ $\mathrm{Hz}, 1 \mathrm{H}), 4.77$ (bs, $1 \mathrm{H}), 3.20(\mathrm{sept}, J=7.0 \mathrm{~Hz}, 1 \mathrm{H}), 2.94-2.80(\mathrm{~m}, 2 \mathrm{H}), 2.80-2.68(\mathrm{~m}$, $2 \mathrm{H}), 2.16(\mathrm{~s}, 3 \mathrm{H}), 1.26(\mathrm{~d}, J=6.9 \mathrm{~Hz}, 6 \mathrm{H})$

${ }^{13} \mathrm{C}$ NMR: $\left(125 \mathrm{MHz}, \mathrm{CDCl}_{3}\right): \delta 208.8,151.2,134.5,133.1,126.3,126.2,115.3,110,45.7$, $30.1,29.3,27,22.6$

HRMS calc'd for $\mathrm{C}_{13} \mathrm{H}_{17} \mathrm{BrO}_{2}:[\mathrm{M}+\mathrm{H}]$ 285.0485. Found: 285.0471

\section{4-(4-hydroxy-3-isopropyl-5-((trimethylsilyl)ethynyl)phenyl)butan-2-one (9)}

To a dry flask was added $1 \mathrm{~g}$ of 8 (3.5 mmol, $1.0 \mathrm{eq}), 92 \mathrm{mg}$ of triphenylphosphine $\left(\mathrm{PPh}_{3}\right.$; $0.35 \mathrm{mmol}, \quad 0.1 \mathrm{eq}), 153 \mathrm{mg}$ of bis(triphenylphosphine)palladium(II)dichloride $\left(\mathrm{PdCl}_{2}\left(\mathrm{PPh}_{3}\right)_{2} ; 0.22 \mathrm{mmol}, 0.06 \mathrm{eq}\right), 239 \mathrm{mg}$ of copper(I) iodide (Cul; $1.26 \mathrm{mmol}, 0.36 \mathrm{eq}$ ) and $1 \mathrm{~mL}$ of ethynyltrimethylsilane $(10.5 \mathrm{mmol}, 3.0 \mathrm{eq})$, and triethylamine $(23 \mathrm{~mL})$ sequentially. This flask was flushed with argon for 15 minutes. The reaction proceeded overnight at room temperature. The mixture was then diluted with water and DCM. The layers were separated, and the aqueous phase was extracted with DCM. The combined organic phases were dried over $\mathrm{Na}_{2} \mathrm{SO}_{4}$ and concentrated in vacuo. The crude material was purified using a Teledyne Isco CombiFlash system (15\% ethyl acetate in hexanes as eluent) yielding $630 \mathrm{mg}(59 \%)$ of 9 as a light brown oil.

${ }^{1} \mathrm{H}$ NMR $\left(500 \mathrm{MHz}, \mathrm{CDCl}_{3}\right): \delta 7.02(\mathrm{~s}, 1 \mathrm{H}), 6.99(\mathrm{~s}, 1 \mathrm{H}), 5.87$ (s, 1H), 3.25 (sept, $J=6.9$ $\mathrm{Hz}, 1 \mathrm{H}$ ), 2.79 (ddd J = 8.5, 6.8, 1.7 Hz, 2H), 2.72 (ddd, J = 8.5, 7.0, 1.7 Hz, 2H), 2.15 (s, $3 \mathrm{H}), 1.23(\mathrm{~d}, J=6.8 \mathrm{~Hz}, 6 \mathrm{H})$

${ }^{13} \mathrm{C}$ NMR: $\left(125 \mathrm{MHz}, \mathrm{CDCl}_{3}\right): \delta 208,152.8,134.2,132.4,127.8,109,101.9,99.6,45.4$, $30.1,29,27.5,22.4,22.3$

HRMS calc'd for $\mathrm{C}_{18} \mathrm{H}_{26} \mathrm{O}_{2} \mathrm{Si}$ : [M + H] 303.1775. Found 303.1656

\section{4-(4-((tert-butyldimethylsilyl)oxy)-3-isopropyl-5-((trimethylsilyl)ethynyl)butan-2- one (10)}

Under an atmosphere of nitrogen, $0.75 \mathrm{~mL}$ of DMF was added to $100 \mathrm{mg}$ of 9 (0.331 $\mathrm{mmol}, 1.0 \mathrm{eq})$ in a round-bottomed flask with stirring. Then $85 \mathrm{mg}$ of imidazole (1.34 $\mathrm{mmol}, 3.75 \mathrm{eq})$ and $137 \mathrm{mg}$ of TBSCl $(0.91 \mathrm{mmol}, 2.75 \mathrm{eq})$ were added. After proceeding overnight at room temperature, the reaction was partitioned between hexanes and water. The aqueous layer was extracted with hexanes. The combined organic layers were washed with water and saturated $\mathrm{NaHCO}_{3}$, dried over $\mathrm{Na}_{2} \mathrm{SO}_{4}$, and concentrated in vacuo. Following purification using a Teledyne Isco CombiFlash system (20\% ethyl 
acetate in hexanes as eluent), the appropriate fractions were combined and concentrated to yield $113 \mathrm{mg}(82 \%)$ of 10 as a light brown oil.

${ }^{1} \mathrm{H}$ NMR $\left(500 \mathrm{MHz}, \mathrm{CDCl}_{3}\right): \delta 7.08(\mathrm{~s}, 1 \mathrm{H}), 6.98(\mathrm{~s}, 1 \mathrm{H}), 3.28$ (sept, J = 11.4, 8.2, $5.4 \mathrm{~Hz}$, $1 \mathrm{H}), 2.88-2.76(\mathrm{~m}, 2 \mathrm{H}), 2.73(\mathrm{ddd}, \mathrm{J}=9.0,5.1,1.9 \mathrm{~Hz}, 2 \mathrm{H}), 2.15(\mathrm{~s}, 1 \mathrm{H}), 1.14(\mathrm{dd}, \mathrm{J}=$ 7.1, 2.6 Hz, 6H), $1.05(\mathrm{~s}, 9 \mathrm{H}), 0.24(\mathrm{~d}, \mathrm{~J}=3.6 \mathrm{~Hz}, 6 \mathrm{H})$

${ }^{13} \mathrm{C}$ NMR $\left(125 \mathrm{MHz}, \mathrm{CDCl}_{3}\right): \delta 208,151.5,140,133.7,131.5,127.1,115.1,101.1,97.4$, $45.3,30.1,29,26.3,26.1,23.1,18.7,0,-3$

HRMS calc'd for $\mathrm{C}_{24} \mathrm{H}_{40} \mathrm{O}_{2} \mathrm{Si}_{2}:[\mathrm{M}+\mathrm{H}]$ 417.2640. Found: 417.2529.

\section{4-(4-((tert-butyldimethylsilyl)oxy)-3-isopropyl-5-((trimethylsilyl)rhynyl)phenethyl)- 3-methyl-3H-diazirine (11)}

Under an atmosphere of nitrogen, $61 \mathrm{mg}$ of $10(0.146 \mathrm{mmol}, 1.0 \mathrm{eq})$ was dissolved in a mixture of methanol-ether $(1: 1,0.6 \mathrm{~mL})$ and cooled to $-40^{\circ} \mathrm{C}$. A solution of $2.0 \mathrm{M} \mathrm{NH}_{3}$ in $\mathrm{MeOH}(8 \mathrm{~mL})$ was added dropwise with stirring over 6 hours. A solution of hydroxylamineO-sulfononic acid ( $25 \mathrm{mg}, 0.220 \mathrm{mmol}, 1.5 \mathrm{eq}$ ) in $0.5 \mathrm{~mL}$ of methanol was added dropwise with stirring. After 1 hour, the flask was kept at $-20^{\circ} \mathrm{C}$ for 2 days with occasional stirring. The mixture was filtered, dried with $\mathrm{Na}_{2} \mathrm{SO}_{4}$, concentrated in vacuo. Crude material was dissolved in a mixture of methanol $(2.4 \mathrm{~mL})$ and $0.062 \mathrm{~mL}$ of triethylamine $(0.442 \mathrm{mmol}$, 3.01 eq.), and cooled to $-10^{\circ} \mathrm{C}$. After stirring for 15 minutes, a solution of iodine ( $37 \mathrm{mg}$, $0.146 \mathrm{mmol}, 1.0 \mathrm{eq})$ in $\mathrm{DCM}(1.2 \mathrm{~mL})$ was added dropwise while stirring. Once the solution remained persistently brown in color, the excess iodine was quenched with a $5 \%$ solution of $\mathrm{Na}_{2} \mathrm{~S}_{2} \mathrm{O}_{3}(0.7 \mathrm{~mL})$, which turned the reaction yellow. The mixture was diluted with water and the aqueous layer was extracted with ether. The combined organic phases were washed with water and dried over $\mathrm{Na}_{2} \mathrm{SO}_{4}$. Concentration and purification using a Teledyne Isco CombiFlash system ( $20 \%$ ethyl acetate in hexanes as eluent) yielded 20 $\mathrm{mg}(32 \%)$ of diazirine 11 as a yellow oil.

${ }^{1} \mathrm{H}$ NMR (500 MHz, CDCl $): \delta 7.06$ (s, 1H), 6.97 (s, 1H), 3.29 (sept, J = $\left.6.9 \mathrm{~Hz}, 1 \mathrm{H}\right), 2.53$ $-2.26(\mathrm{~m}, 2 \mathrm{H}), 1.80-1.59(\mathrm{~m}, 2 \mathrm{H}), 1.15(\mathrm{~d}, \mathrm{~J}=6.9 \mathrm{~Hz}, 1.15(\mathrm{~d}, \mathrm{~J}=6.9 \mathrm{~Hz}, 6 \mathrm{H}), 1.05(\mathrm{~s}$, $9 \mathrm{H}), 1.01(\mathrm{~s}, 3 \mathrm{H}), 0.41-0.20(\mathrm{~m}, 6 \mathrm{H}), 0.10(\mathrm{~s}, 9 \mathrm{H})$

${ }^{13} \mathrm{C}$ NMR $\left(125 \mathrm{MHz}, \mathrm{CDCl}_{3}\right): 151.5,139.9,133.5,131.5,127.1,127,115.1,104.1,97.4$, $36.5,29.3,26.3,26.1,25.7,23.1,20,18.7,0.01,-2.9$

HRMS calc'd for $\mathrm{C}_{24} \mathrm{H}_{40} \mathrm{~N}_{2} \mathrm{OSi}_{2}:[\mathrm{M}+\mathrm{H}]$ 429.2752. Found: 429.2750

\section{2-ethynyl-6-isopropyl-4-(2-(3-methyl-3H-diazirin-3-yl)ethyl)phenol (12)}

Under an atmosphere of nitrogen, $20 \mathrm{mg}$ of $11(0.046 \mathrm{mmol}, 1.0 \mathrm{eq})$ was deprotected with dropwise addition of TBAF-acetic acid $(0.014 \mathrm{~mL}$ of $1.0 \mathrm{M}$ in THF $+0.040 \mathrm{~mL}$ neat THF) 
on ice. The reaction was allowed to warm to room temperature overnight to obtain crude product. Purification using a Teledyne Isco CombiFlash system (10\% ethyl acetate in hexanes as eluent) yielded $12 \mathrm{mg}(53 \%)$ of 12 as a yellow oil after concentration.

${ }^{1} \mathrm{H}$ NMR (500 MHz, CDCl $): \delta 7.03$ (s, 1H), 7.00 (s, 1H), $5.79(\mathrm{~s}, 1 \mathrm{H}), 3.46(\mathrm{~s}, 1 \mathrm{H}), 3.28$ (sept, J=6.9 Hz, 1H), $2.39(\mathrm{~m}, 2 \mathrm{H}), 1.63(\mathrm{~m}, 2 \mathrm{H}), 1.24(\mathrm{~d}, \mathrm{~J}=6.9 \mathrm{~Hz}, 6 \mathrm{H}), 1.02(\mathrm{~s}, 3 \mathrm{H})$

${ }^{13} \mathrm{C}$ NMR: (125 MHz, $\left.\mathrm{CDCl}_{3}\right):$ 153, 135, 132, 129, 128, 108, 84, 79, 37, 29, 27, 26, 22, 20

HRMS calc'd for $\mathrm{C}_{15} \mathrm{H}_{18} \mathrm{~N}_{2} \mathrm{O}:[\mathrm{M}+\mathrm{H}]$ 243.1497. Found: 243.1502

Preparation of $p$-XPRO-Click (18)

\section{4-hydroxy-3,5-diisopropylbenzaldehyde (13)}

13 was synthesized as described in López et al. ${ }^{28} \mathrm{~A}$ solution of 2,6-diisopropylphenol (2.0 $\mathrm{g}, 11.2 \mathrm{mmol}, 1.0 \mathrm{eq}), 3.15 \mathrm{~g}$ of hexamethylenetetramine $(22.4 \mathrm{mmol}, 2.0 \mathrm{eq})$ and $11 \mathrm{~mL}$ of trifluoroacetic acid $\left(\mathrm{F}_{3} \mathrm{CCO}_{2} \mathrm{H}\right)$ were mixed in a round bottomed flask and heated under reflux $\left(90^{\circ} \mathrm{C}\right)$ overnight. The reaction mixture was cooled to room temperature and neutralized with $\mathrm{NaHCO}_{3}$. The aqueous layer was extracted with ethyl acetate and the combined organic layers were concentrated. $3 \mathrm{M} \mathrm{HCl}$ was added to the crude product and the mixture was stirred under reflux $\left(80^{\circ} \mathrm{C}\right)$ for 3 hours. The precipitate was filtered, washed with water, and purified using a Teledyne Isco CombiFlash system (20\% ethyl acetate in hexanes as eluent) to yield $2 \mathrm{~g}$ of 13 as a white solid (90\%).

${ }^{1} \mathrm{H}$ NMR (500 MHz, $\left.\mathrm{CDCl}_{3}\right): \delta 9.88(\mathrm{~s}, 1 \mathrm{H}), 7.64(\mathrm{~s}, 2 \mathrm{H}), 5.41$ (s, 1H), 3.19 (sept, $J=6.9$ $\mathrm{Hz}, 2 \mathrm{H}), 1.33(\mathrm{~d}, 12 \mathrm{H})$

${ }^{13} \mathrm{C}$ NMR: $\left(125 \mathrm{MHz}, \mathrm{CDCl}_{3}\right): \delta 192.9,156.9,134.8,129.1,126.7,27,22.5$

HRMS calc'd for $\mathrm{C}_{13} \mathrm{H}_{18} \mathrm{O}_{2}:[\mathrm{M}+\mathrm{Na}]$ 229.1204. Found: 229.1222.

\section{4-(tert-butyldimethylsilyl)oxy)-3,5-diisopropylbenzaldehyde (14)}

Under an atmosphere of nitrogen, $204 \mathrm{mg}$ of $13(0.989 \mathrm{mmol}, 1.0 \mathrm{eq})$ was dissolved in DCM $(10 \mathrm{~mL})$ and then $0.69 \mathrm{~mL}$ of triethylamine $(4.944 \mathrm{mmol}, 5.0 \mathrm{eq})$ and $179 \mathrm{mg}$ of TBSCl (1.1867 mmol, $1.2 \mathrm{eq})$ were added. The mixture was stirred at room temperature overnight. The mixture was partitioned between hexanes and ethyl acetate, dried over $\mathrm{Na}_{2} \mathrm{SO}_{4}$, and purified using a Teledyne Isco CombiFlash system (100\% hexanes as eluent) to yield $200 \mathrm{mg}$ of $\mathbf{1 4}$ as a yellow oil (63\%).

${ }^{1} \mathrm{H}$ NMR (500 MHz, CDCl $): \delta 9.95$ (s, $\left.1 \mathrm{H}\right), 7.63$ (s, 2H), 3.33 (sept, $J=6.9 \mathrm{~Hz}, 2 \mathrm{H}$ ), 1.22 (d, 12H), $1.04(\mathrm{~d}, J=2.4 \mathrm{~Hz}, 9 \mathrm{H}), 0.25(\mathrm{~s}, 6 \mathrm{H})$ 
${ }^{13} \mathrm{C}$ NMR: (125 MHz, $\left.\mathrm{CDCl}_{3}\right): \delta$ 191.8, 155.4, 140.2, 130.8, 125.9, 26.8, 26, 23.1, 19, -3.2

HRMS calc'd for $\mathrm{C}_{19} \mathrm{H}_{32} \mathrm{O}_{2} \mathrm{Si}[\mathrm{M}+\mathrm{H}]: 321.2250$. Found: 321.2280

\section{1-4-((tert-butyldimethylsilyl)oxy)-3,5-diisopropylphenyl)prop-2-yn-1-ol (15)}

Under an atmosphere of nitrogen, $680 \mathrm{mg}$ of $14(2.12 \mathrm{mmol}, 1.0 \mathrm{eq})$ was dissolved in 2 $\mathrm{mL}$ of anhydrous THF and cooled to $-78^{\circ} \mathrm{C}$ via a dry ice-acetone bath. To this solution, 7 $\mathrm{mL}$ of $0.5 \mathrm{M}$ ethynylmagnesium bromide $(\mathrm{HCCMgBr})$ solution in THF was added dropwise. The reaction mixture was allowed to slowly warm to room temperature. After stirring for 3 hours at room temperature, the reaction was quenched with saturated ammonium chloride $\left(\mathrm{NH}_{4} \mathrm{Cl}\right)$, and the mixture was partitioned between DCM and water, and the two layers were separated. The organic layer was washed with water, dried over $\mathrm{Na}_{2} \mathrm{SO}_{4}$ and concentrated in vacuo. Crude material was purified using a Teledyne Isco CombiFlash system (15\% ethyl acetate in hexanes as eluent) to give $570 \mathrm{mg}(83 \%)$ of 15 as a brownish oil.

${ }^{1} \mathrm{H}$ NMR $\left(500 \mathrm{MHz}, \mathrm{CDCl}_{3}\right): \delta 7.28(\mathrm{~s}, 2 \mathrm{H}), \delta 5.58-5.33(\mathrm{~m}, 1 \mathrm{H}), 3.32$ (sept, $J=6.9 \mathrm{~Hz}$, $2 \mathrm{H}), 2.76-2.63(\mathrm{~m}, 2 \mathrm{H}), 1.19(\mathrm{~d}, 12 \mathrm{H}), 1.05(\mathrm{~s}, 9 \mathrm{H}), 0.21(\mathrm{~s}, 6 \mathrm{H})$

${ }^{13} \mathrm{C}$ NMR: (125 MHz, $\left.\mathrm{CDCl}_{3}\right):$ 149.6, 139.4, 133, 122.1, 83.9, 74.5, 64.8, 26.8, 26.1, 23.3, $18.9,-3.29$

HRMS calc'd for $\mathrm{C}_{21} \mathrm{H}_{34} \mathrm{O}_{2} \mathrm{Si}[\mathrm{M}+\mathrm{Na}]$ : 369.2226. Found 369.2229.

\section{4-(4-((tert-butyldimethylsilyl)oxy)-3,5-diisopropylphenyl)hex-5-yn-2-one (16)}

16 was synthesized according to Nishibayashi et al. ${ }^{19}$ Under an atmosphere of nitrogen, $7 \mathrm{mg}$ of ammonium tetrafluoroborate $\left(\mathrm{NH}_{4} \mathrm{BF}_{4} ; 0.066 \mathrm{mmol}, 0.1 \mathrm{eq}\right)$ and $21 \mathrm{mg}$ of $\left[\mathrm{Cp}{ }^{*} \mathrm{RuCl}\left(\mu_{2}-\mathrm{SMe}\right)_{2} \mathrm{RuCp}{ }^{*} \mathrm{Cl}\right](0.033 \mathrm{mmol}, 0.05 \mathrm{eq})$ were placed in a round-bottomed flask. Anhydrous acetone $(40 \mathrm{~mL})$ was added, and then the mixture was stirred at room temperature. After addition of $230 \mathrm{mg}$ of $15(0.66 \mathrm{mmol}, 1.0 \mathrm{eq})$, the reaction flask was kept at reflux temperature for 5 hours. The reaction mixture was treated with brine (20 $\mathrm{mL}$ ) and extracted with diethyl ether $(20 \mathrm{~mL} \times 3)$. The ether layer was dried over anhydrous $\mathrm{Na}_{2} \mathrm{SO}_{4}$. The extract was concentrated under reduced pressure and purified using a Teledyne Isco CombiFlash system ( $10 \%$ ethyl acetate in hexanes as eluent) to give 16 as a light brown oil ( $83 \%$ yield).

${ }^{1} \mathrm{H}$ NMR $\left(500 \mathrm{MHz}, \mathrm{CDCl}_{3}\right): \delta 7.04(\mathrm{~s}, 2 \mathrm{H}), \delta 4.13$ (ddd, $\left.J=9.2,5.5,2.4 \mathrm{~Hz}, 1 \mathrm{H}\right), 3.29$ (hept, $J=6.9 \mathrm{~Hz}, 2 \mathrm{H}$ ), 2.98 (dd, $J=16.1,9.1 \mathrm{~Hz}, 1 \mathrm{H}) 2.78(\mathrm{dd}, J=16.2,5.5 \mathrm{~Hz}, 1 \mathrm{H}), 2.28$ (s, 1H), $2.16(\mathrm{~s}, 3 \mathrm{H}), 1.17(\mathrm{~d}, 12 \mathrm{H}), 1.03(\mathrm{~s}, 9 \mathrm{H}), 0.19(\mathrm{~s}, 6 \mathrm{H})$

${ }^{13} \mathrm{C}$ NMR: $\left(125 \mathrm{MHz}, \mathrm{CDCl}_{3}\right): 206.2$ 148.2, 139.3, 132.9, 130.9, 128.8, 122.2, 85.5, 70.9, $52.1,38.7,32.7,30.7,29,26.7,26.1,23.4,23,18.9,-3.3$ 
HRMS calc'd for $\mathrm{C}_{24} \mathrm{H}_{38} \mathrm{O}_{2} \mathrm{Si}[\mathrm{M}+\mathrm{H}]: 387.2719$. Found 387.2787.

\section{3-(2-(4-((tert-butyldimethylsilyl)oxy)-3,5-diisopropylphenyl)but-3-yn-1-yl)-3-methyl- 3H-diazirine (17)}

Under an atmosphere of nitrogen, $160 \mathrm{mg}$ of $16(0.425 \mathrm{mmol}, 1.0 \mathrm{eq})$ was dissolved in methanol $(1.5 \mathrm{~mL})$ and cooled to $-40^{\circ} \mathrm{C}$ with a dry ice/acetonitrile bath. A solution of 2.0 $\mathrm{M}$ ammonia in methanol $(11 \mathrm{~mL})$ was added dropwise with stirring. The reaction mixture was warmed up to $-30^{\circ} \mathrm{C}$ and stirred at this temperature for 6 hours. A solution of hydroxylamine-O-sulfonic acid $(74 \mathrm{mg}, 0.64 \mathrm{mmol})$ in $1.2 \mathrm{~mL}$ of methanol was added dropwise and the solution was stirred at $-20^{\circ} \mathrm{C}$ for 2 days. After completion, the reaction mixture was evaporated under reduced pressure and dissolved in a mixture of methanol $(6.4 \mathrm{~mL})$ and $0.192 \mathrm{~mL}$ of triethylamine $(1.28 \mathrm{mmol}, 3.0 \mathrm{eq})$ and cooled to $-10^{\circ} \mathrm{C} . \mathrm{A}$ saturated solution of iodine (109 $\mathrm{mg}, 0.425 \mathrm{mmol}, 1.0 \mathrm{eq})$ in dichloromethane $(3.2 \mathrm{~mL})$ was added dropwise until the mixture remained light-brown in color. The excess iodine was quenched with $5 \%$ solution of $\mathrm{Na}_{2} \mathrm{~S}_{2} \mathrm{O}_{3}(1.5 \mathrm{~mL})$. The mixture was partitioned between water and ether. The organic phase was collected and washed with water and brine (20 mL each) and dried over $\mathrm{Na}_{2} \mathrm{SO}_{4}$. Concentration in vacuo and purification using a Teledyne Isco CombiFlash system (1\% ethyl acetate in hexanes as eluent) afforded 17 as a light brown oil $(80 \mathrm{mg}, 52 \%)$.

${ }^{1} \mathrm{H}$ NMR (500 MHz, $\left.\mathrm{CDCl}_{3}\right): \delta 7.05(\mathrm{~s}, 2 \mathrm{H}), \delta 3.50$ (ddd, $\left.J=8.9,6.5,2.5 \mathrm{~Hz}, 1 \mathrm{H}\right), 3.29$ (hept, $J=13.8,6.9 \mathrm{~Hz}, 2 \mathrm{H}), 1.17(\mathrm{~d}, 12 \mathrm{H}), 1.04(\mathrm{~s}, 9 \mathrm{H}), 0.97(\mathrm{~s}, 3 \mathrm{H}), 0.19(\mathrm{~s}, 6 \mathrm{H})$

${ }^{13} \mathrm{C}$ NMR: (125 MHz, $\left.\mathrm{CDCl}_{3}\right): 148.2,139.3,132.9,130.9,122.3,71.3 .5,44.3,32.5,26.7$, $26.1,23.4,20.3,18.9,-3.3$

HRMS calc'd for $\mathrm{C}_{24} \mathrm{H}_{38} \mathrm{~N}_{2} \mathrm{OSi}[\mathrm{M}+\mathrm{H}]$ : 399.2832 . Found: 399.2830

\section{2,6-diisopropyl-4-(1-(3-methyl-3H-diazirin-3-yl)but-3-yn-2-yl)phenol (18)}

To a round bottomed flask with $30 \mathrm{mg}$ of $17(0.075 \mathrm{mmol}, 1.0 \mathrm{eq})$ was added $0.113 \mathrm{~mL}$ of TBAF (1.0 M in THF) and $0.013 \mathrm{~mL}$ of acetic acid under an atmosphere of nitrogen. The reaction proceeded overnight and was purified using a Teledyne Isco CombiFlash system (5\% ethyl acetate in hexanes as eluent) to give 18 in $55 \%$ yield.

${ }^{1} \mathrm{H}$ NMR (500 MHz, CDCl $): \delta 7.04$ (s, 2H), $\delta 4.73$ (s, 1H), 3.50 (ddd, $J=9.0,6.5,2.5 \mathrm{~Hz}$, $1 \mathrm{H}), 3.15$ (hept, $J=6.9 \mathrm{~Hz}, 2 \mathrm{H}), 1.89-1.68(\mathrm{~m}, 2 \mathrm{H}), 1.28(\mathrm{~d}, J=6.8 \mathrm{~Hz}, 12 \mathrm{H}), 1.03(\mathrm{~s}, 3 \mathrm{H})$

${ }^{13} \mathrm{C}$ NMR: $\left(125 \mathrm{MHz}, \mathrm{CDCl}_{3}\right): 149.0,133.9,132.0,122.4,85.5,71.4,44.2,32.5,27.3$, 24.8, 22.7, 20.4

HRMS calc'd for $\mathrm{C}_{18} \mathrm{H}_{24} \mathrm{~N}_{2} \mathrm{O}[\mathrm{M}+\mathrm{H}]: 285.1967$. Found: 285.1981 


\section{${ }^{1} \mathrm{H}$ and ${ }^{13} \mathrm{C}$ NMR spectra}

${ }^{1} \mathrm{H}$ NMR spectrum of 4-(4-Hydroxy-3,5-diisopropylphenyl)butan-2-one (2)
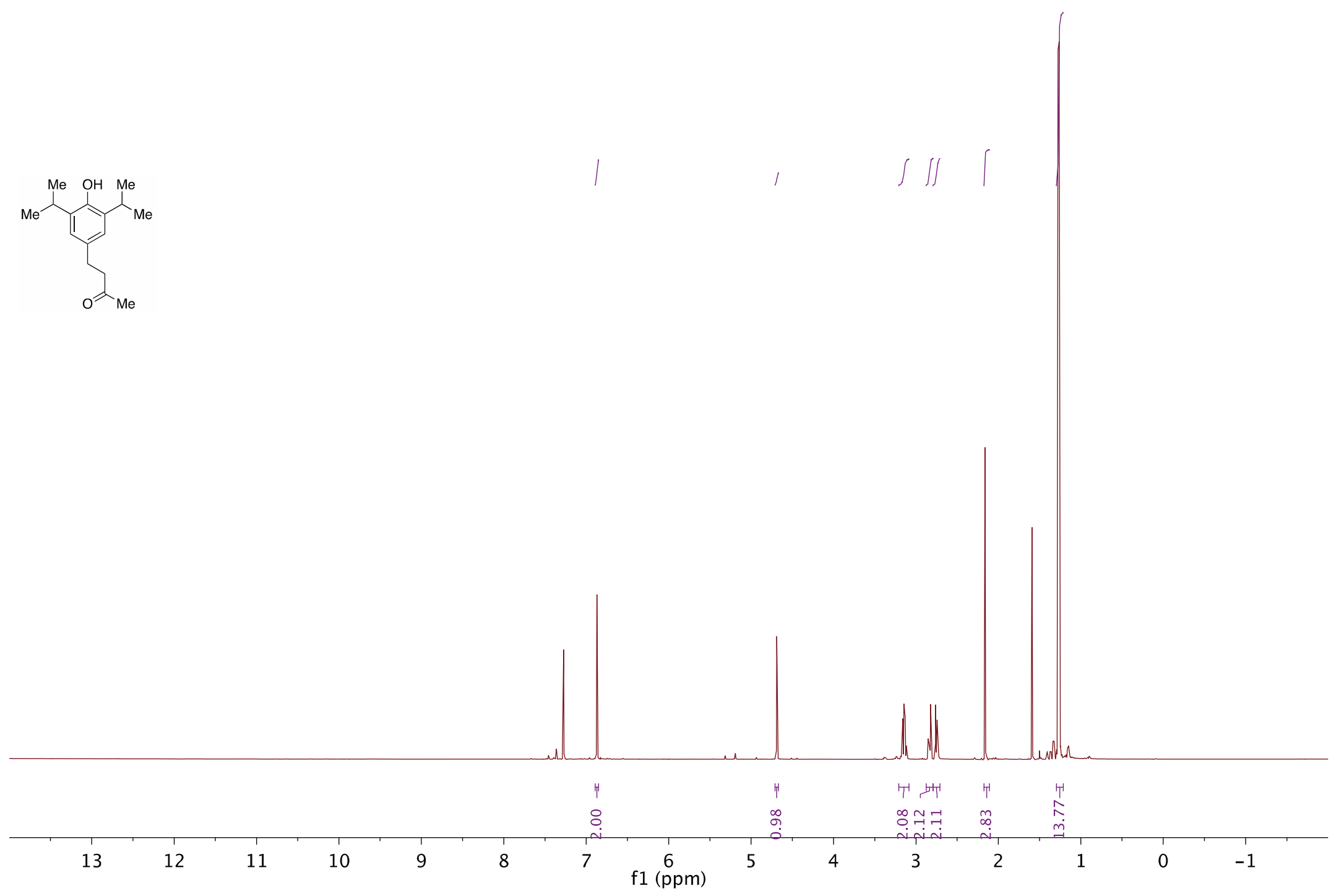
${ }^{13} \mathrm{C}$ NMR spectrum of 4-(4-Hydroxy-3,5-diisopropylphenyl)butan-2-one (2)

KS_Progrofol_Ketone_CNMR

KJS-01œ070 fractions 33-50

$\stackrel{\sim}{i}$
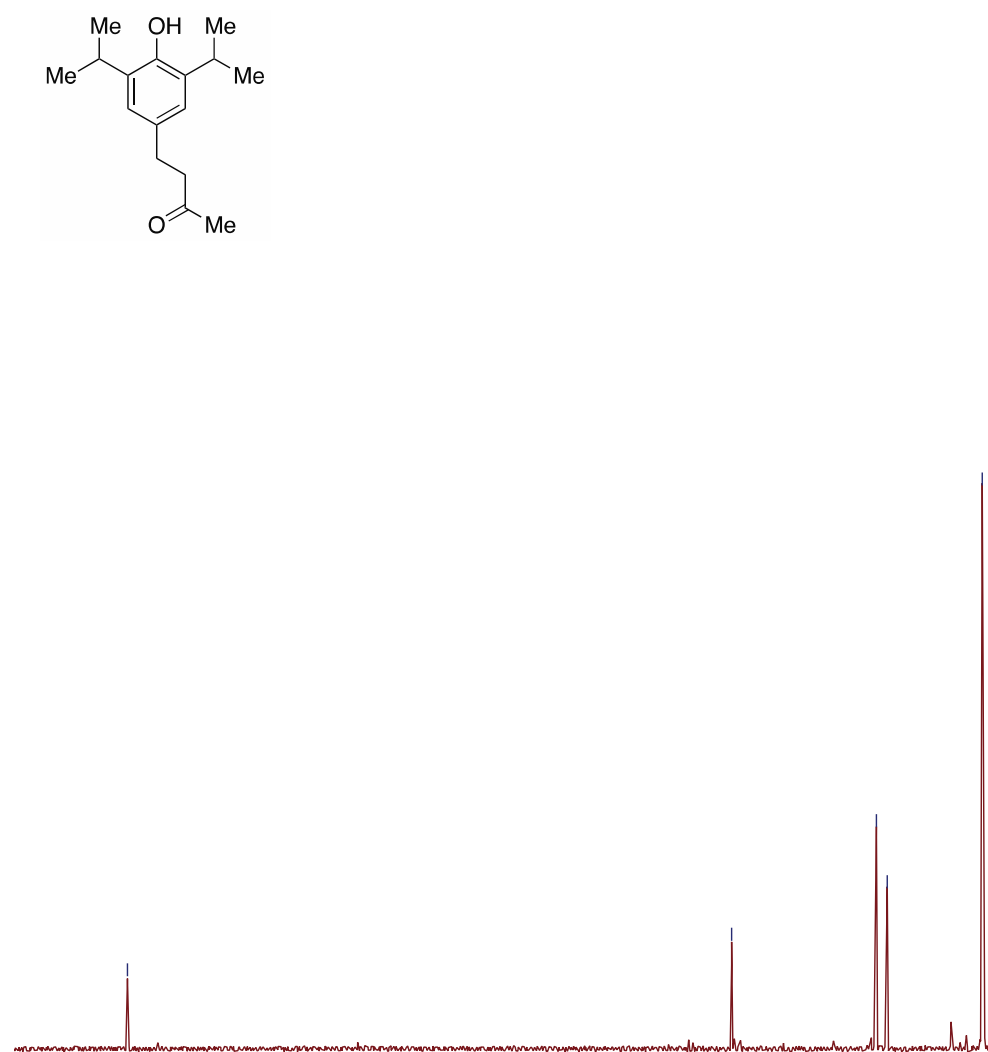

$\widehat{C}_{\mathrm{Me}}$

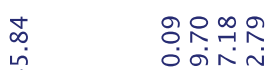

iñ

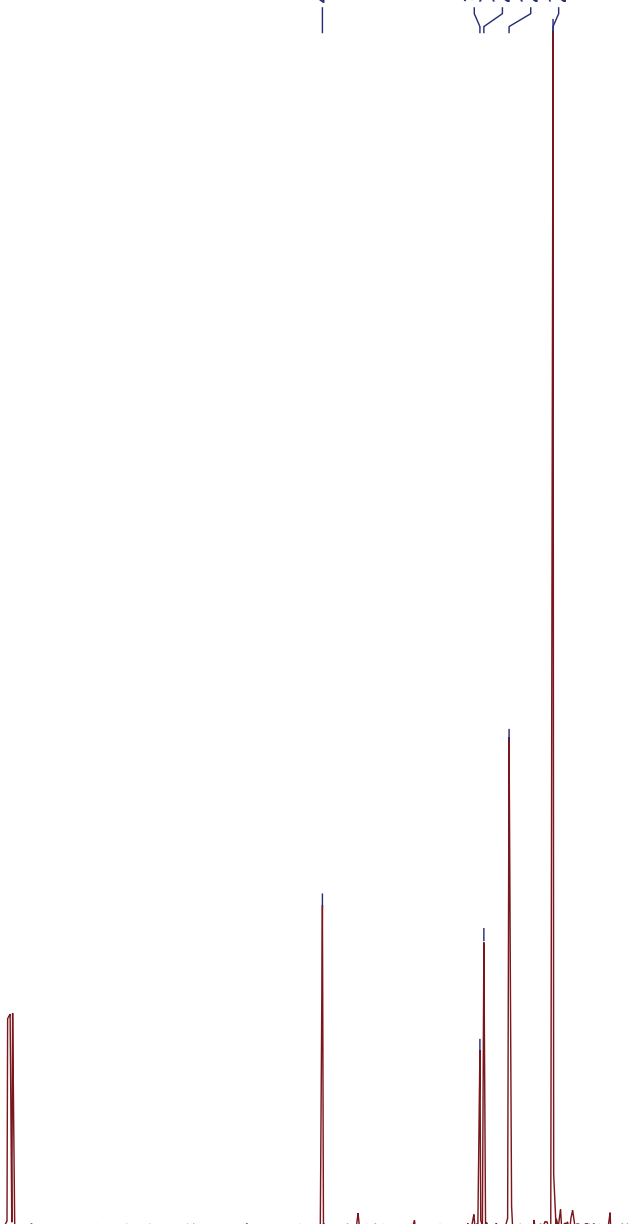

$210 \quad 200 \quad 190$

$180 \quad 170 \quad 160$

$150 \quad 140$

130

$120 \quad 110$

100

$90 \quad 80$

70

60

50

4030 
${ }^{1} \mathrm{H}$ NMR spectrum of 4-[4-(tert-Butyldimethylsilyloxy)-3,5-diisopropylphenyl]butan-2-one (3)

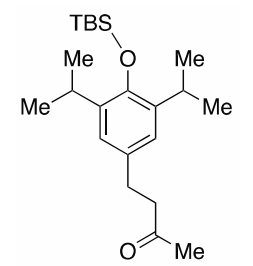


${ }^{13} \mathrm{C}$ NMR spectrum of 4-[4-(tert-Butyldimethylsilyloxy)-3,5-diisopropylphenyl]butan-2-one (3)

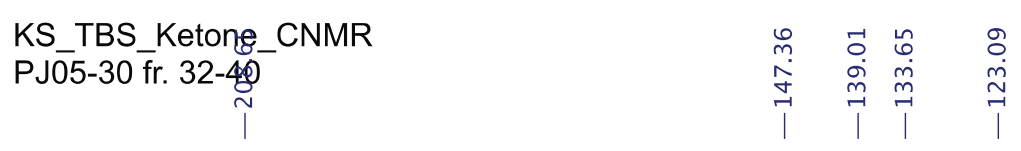

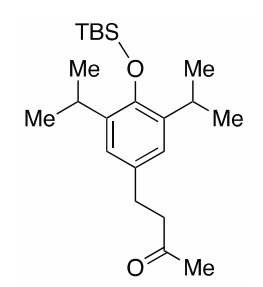

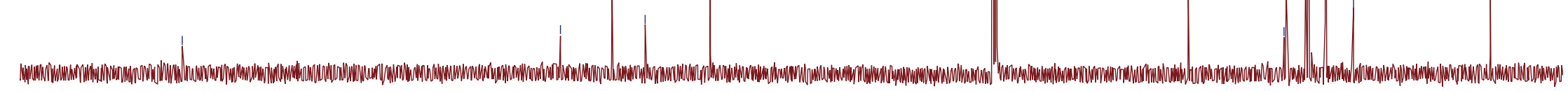

$\begin{array}{lllllllllllllllllllllllllllllllll}230 & 220 & 210 & 200 & 190 & 180 & 170 & 160 & 150 & 140 & 130 & 120 & 110 & 100 & 90 & 80 & 70 & 60 & 50 & 40 & 30 & 20 & 10 & 0 & -10\end{array}$ 
${ }^{1} \mathrm{H}$ NMR spectrum of 3-[4-(tert-Butyldimethylsilyl)oxy)-3,5-diisopropylphenyl]-3-methyl-3H-diazirine (4)
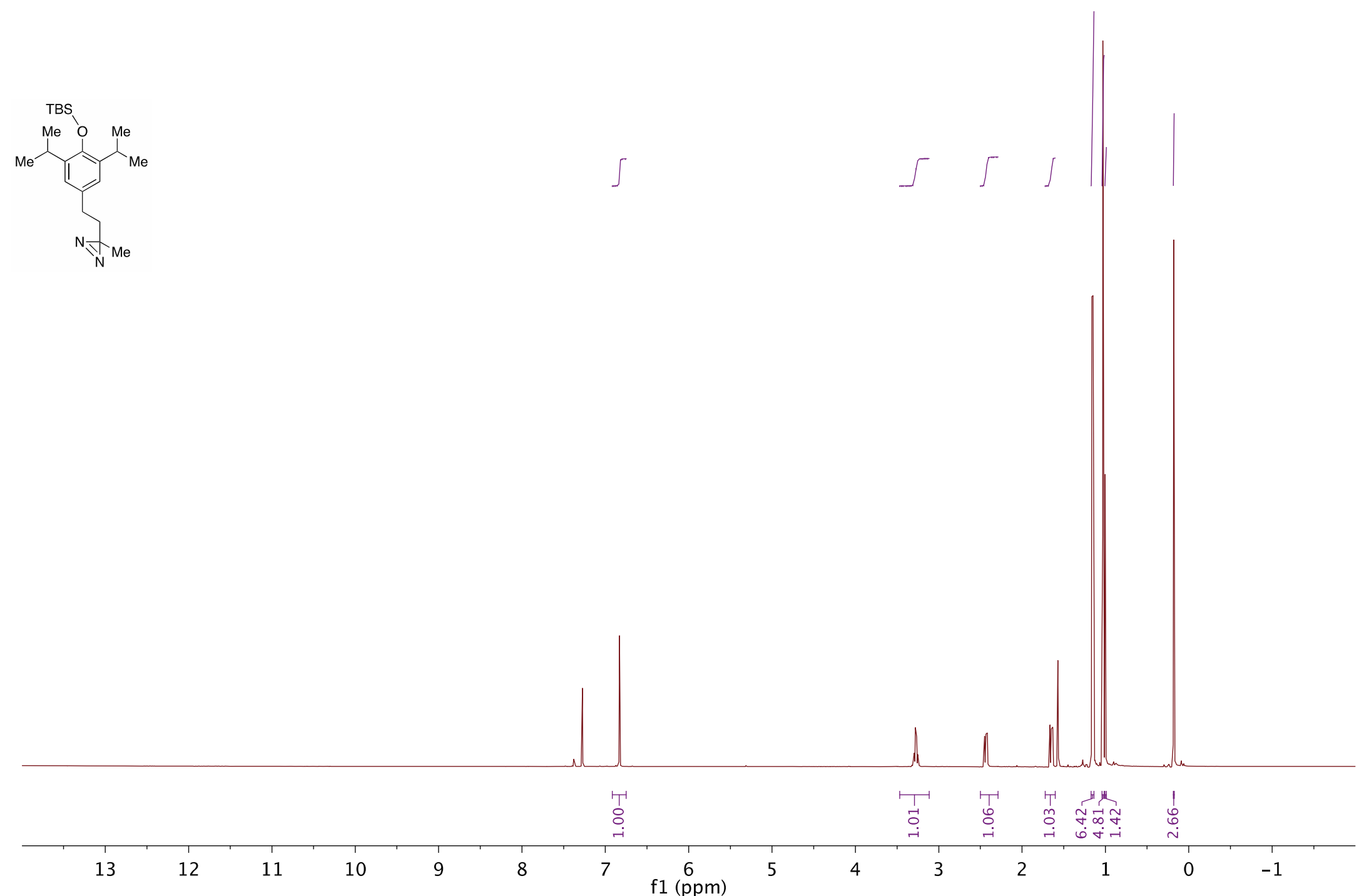
${ }^{13} \mathrm{C}$ NMR spectrum of 3-[4-(tert-Butyldimethylsilyl)oxy)-3,5-diisopropylphenyl]-3-methyl-3H-diazirine (4)

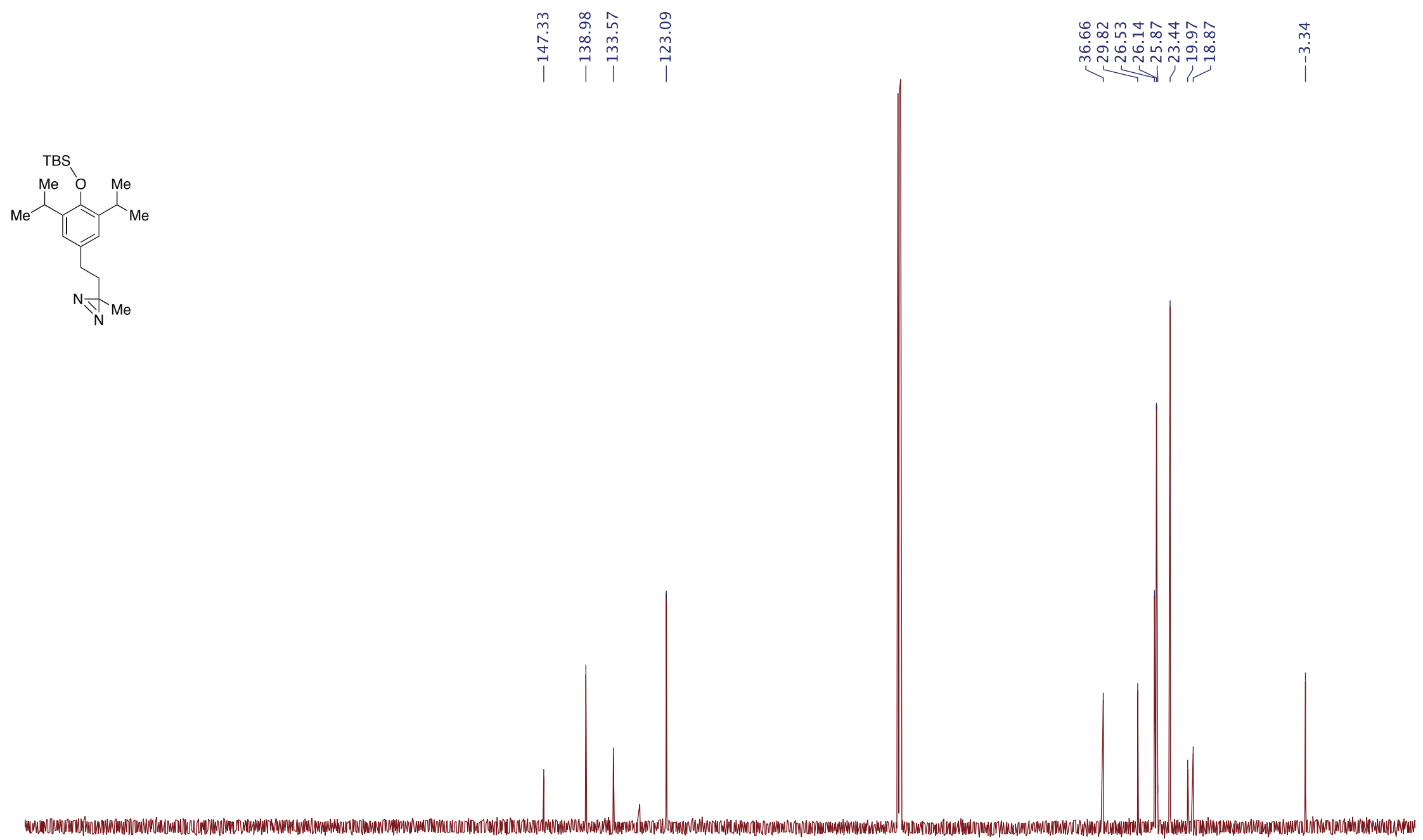

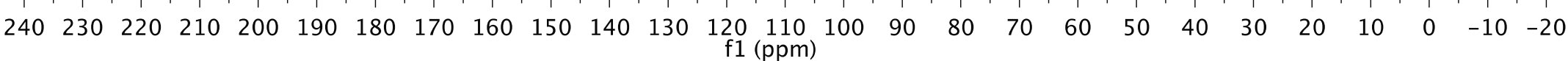


${ }^{1}$ H NMR spectrum of 2,6-Diisopropyl-4-[2-(3-methyl-3H-diazirin-3-yl)ethyl]phenol (5)
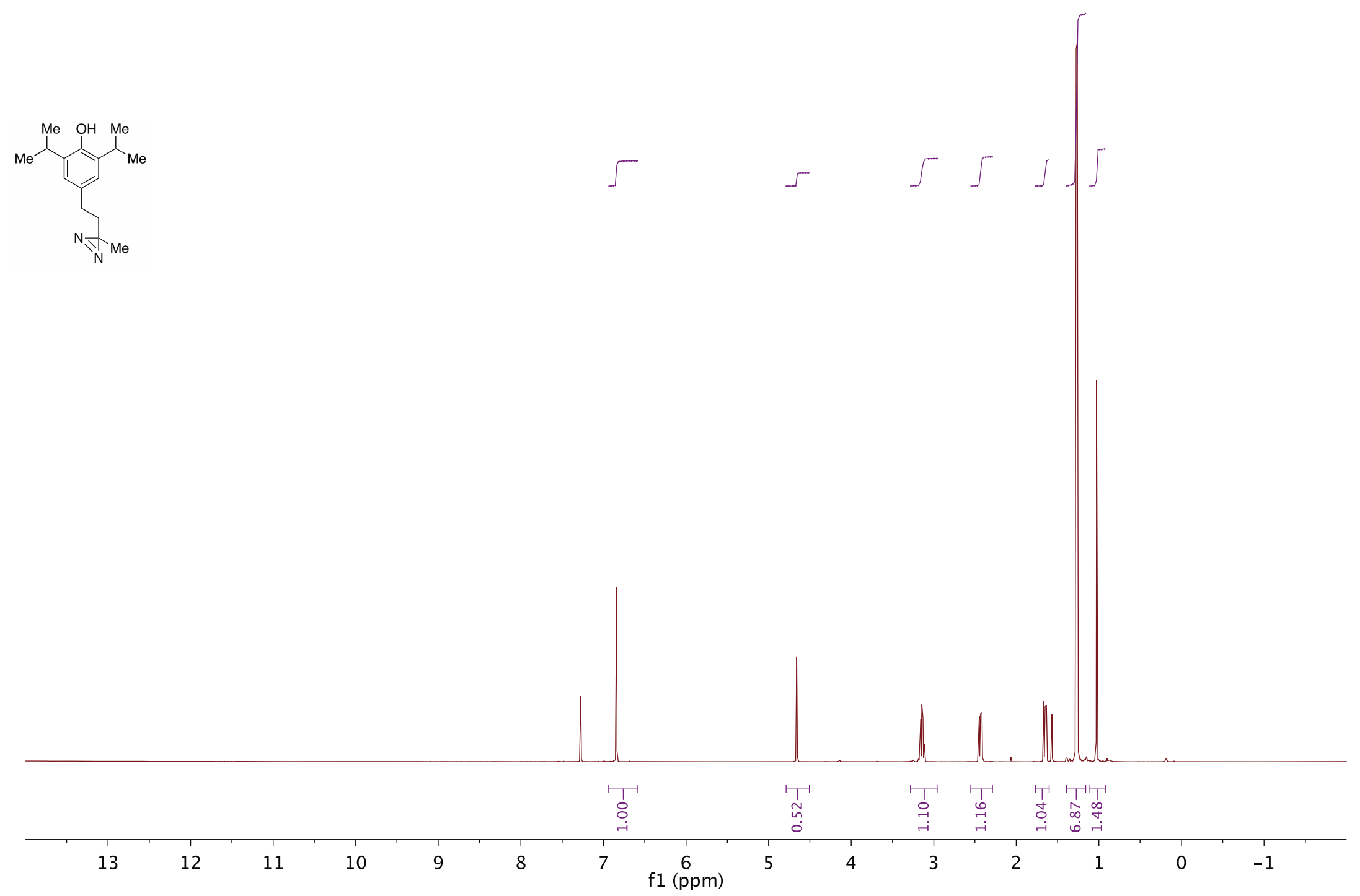
${ }^{13} \mathrm{C}$ NMR spectrum of 2,6-Diisopropyl-4-[2-(3-methyl-3H-diazirin-3-yl)ethyl]phenol (5)
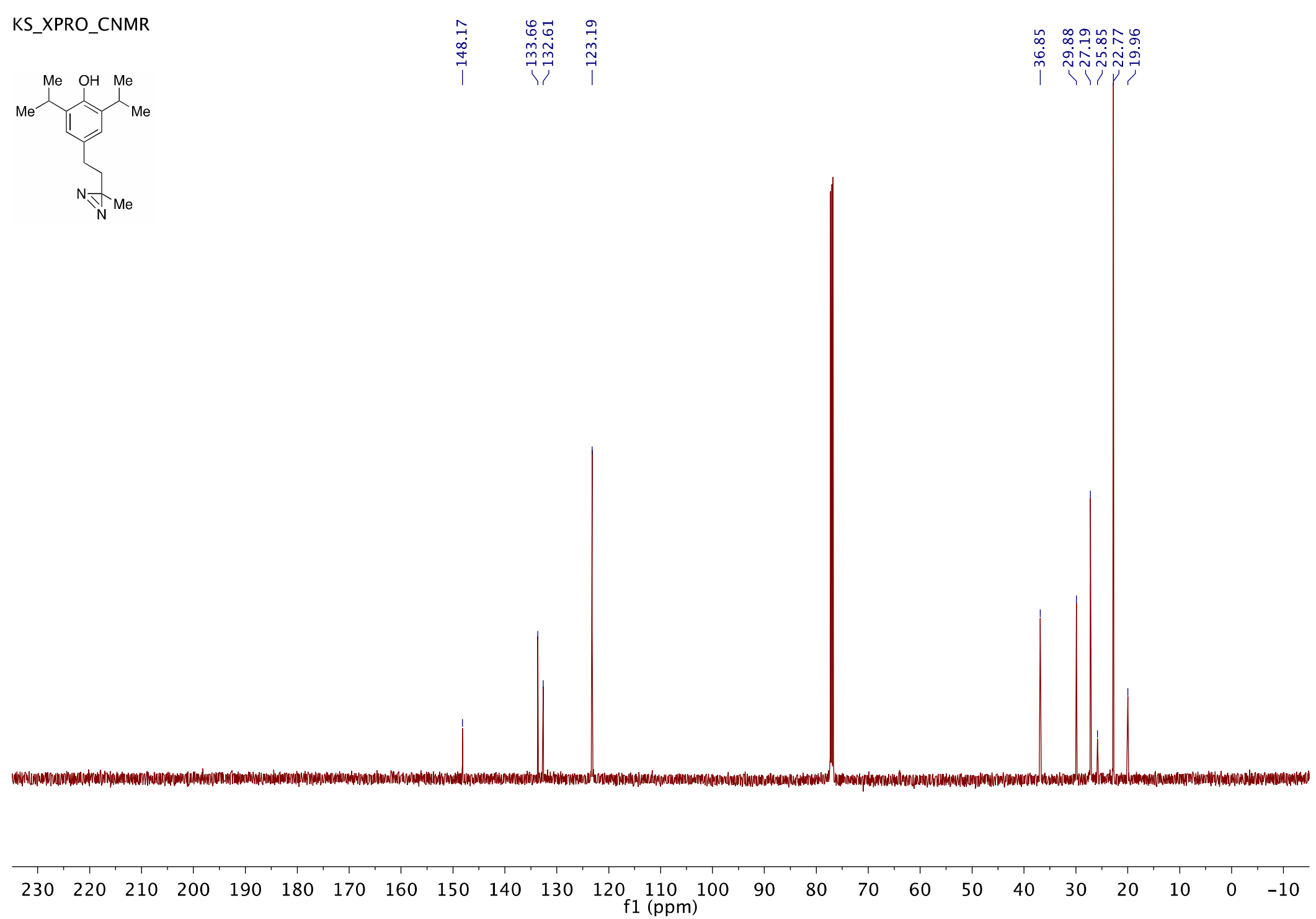
${ }^{1} \mathrm{H}$ NMR spectrum of 4-(4-hydroxy-3-isopropylphenyl)butan-2-one (7)

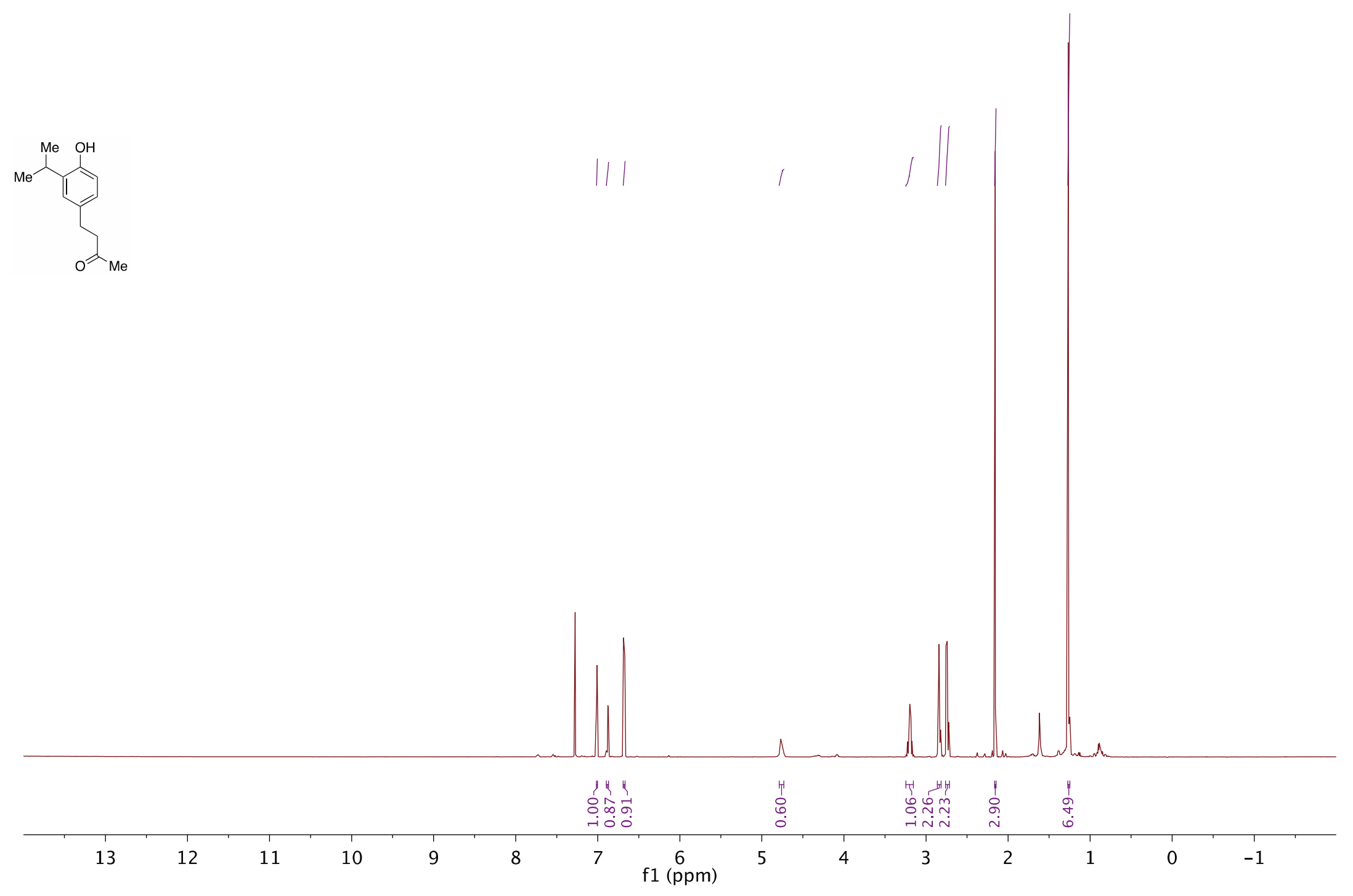


${ }^{13} \mathrm{C}$ NMR spectrum of 4-(4-hydroxy-3-isopropylphenyl)butan-2-one (7)

Aug2115PhenotMVKAddtn_CNMR EMW.533A.IV- 整1.1500C

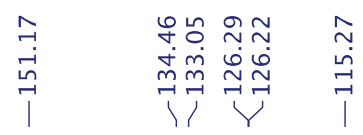
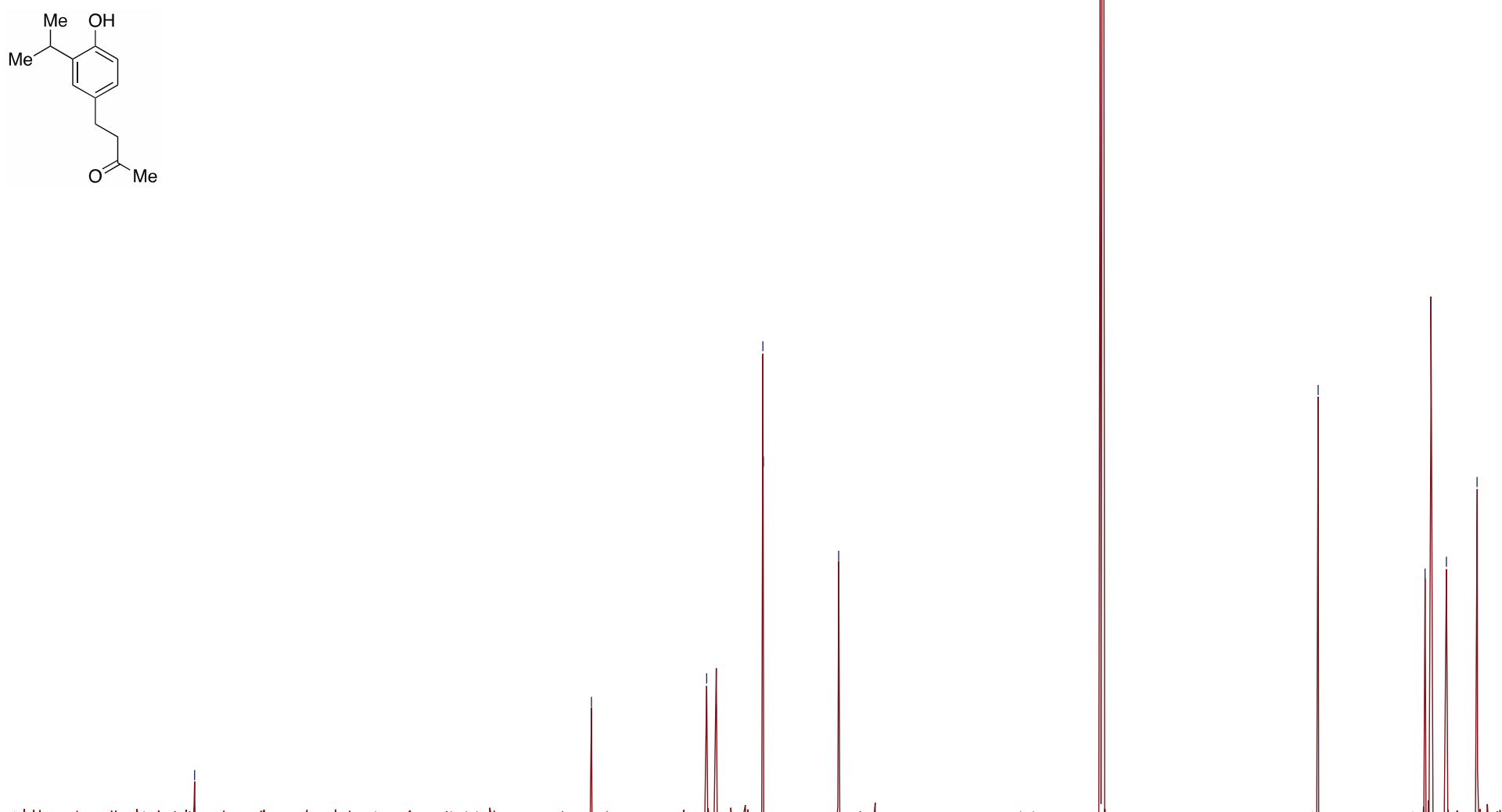

14W.

$\begin{array}{lllllllllllllllllllllllll}230 & 220 & 210 & 200 & 190 & 180 & 170 & 160 & 150 & 140 & 130 & 120 & 110 & 100 & 90 & 80 & 70 & 60 & 50 & 40 & 30 & 20 & 10 & 0 & -10\end{array}$


${ }^{1} \mathrm{H}$ NMR spectrum of 4-(3-bromo-4-hydroxy-5-isopropylphenyl)butan-2-one (8)
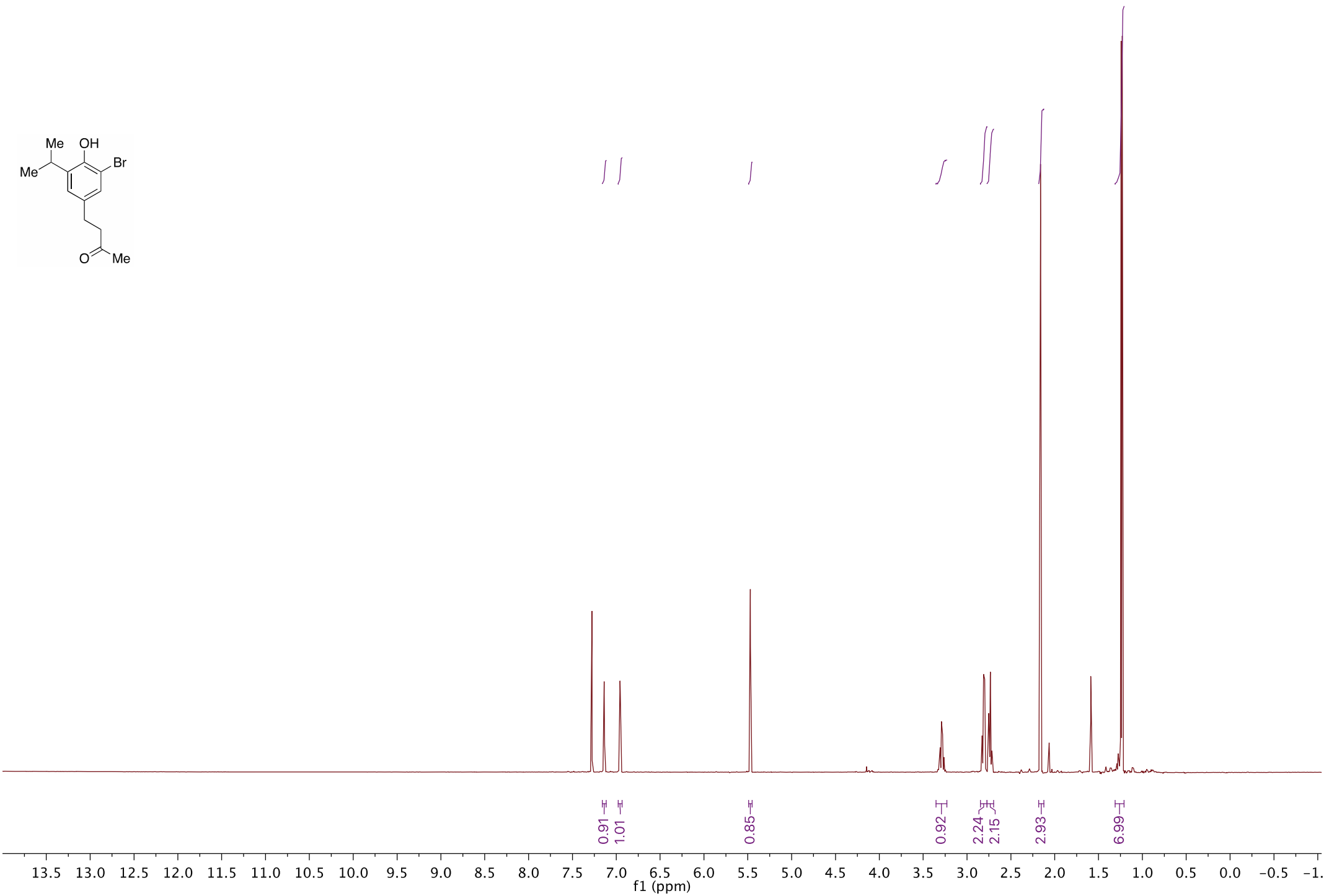
${ }^{13} \mathrm{C}$ NMR spectrum of 4-(3-bromo-4-hydroxy-5-isopropylphenyl) butan-2-one (8)
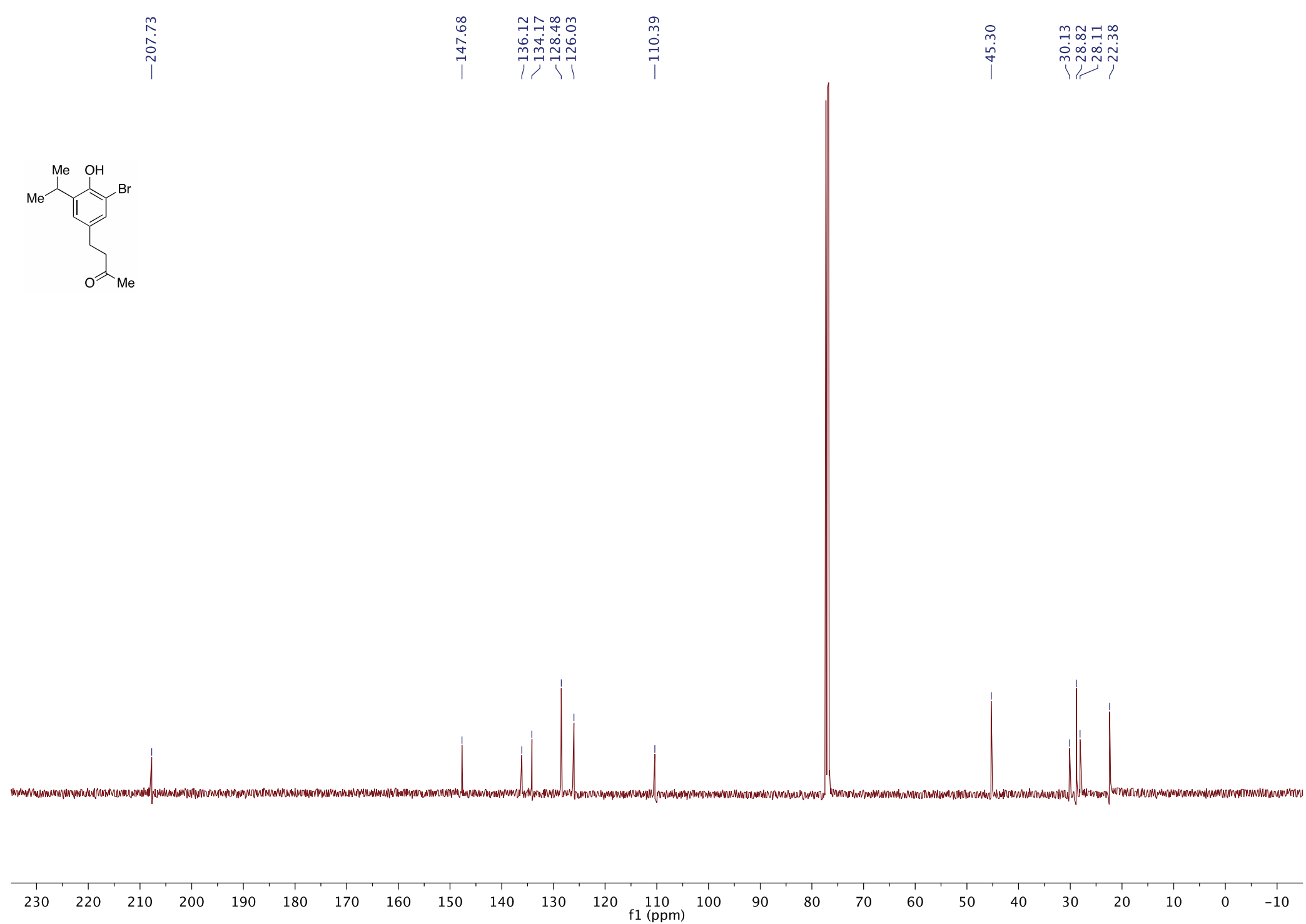
${ }^{1}$ H NMR spectrum of 4-(4-hydroxy-3-isopropyl-5-((trimethylsilyl)ethynyl)phenyl)butan-2-one (9)
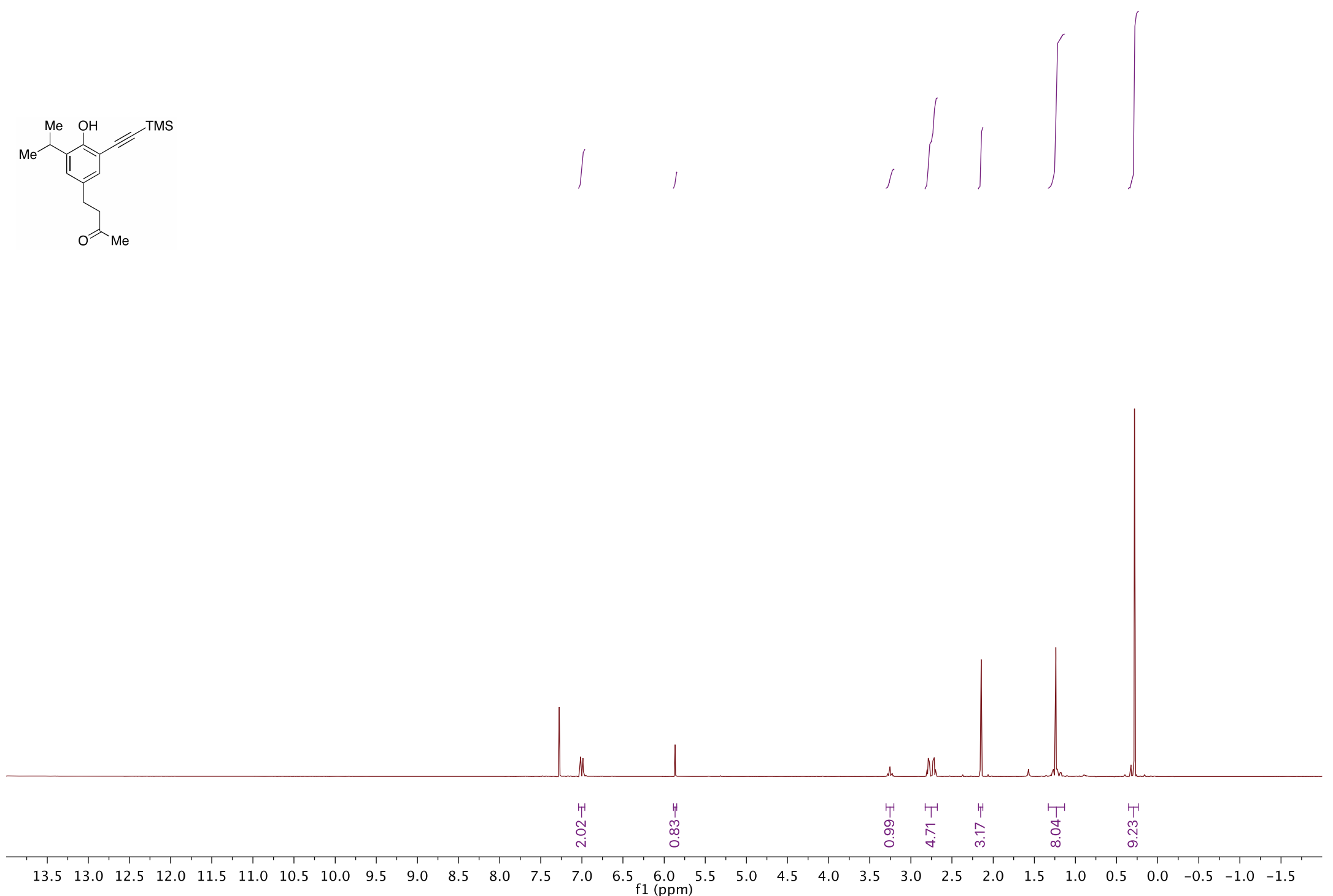
${ }^{13} \mathrm{C}$ NMR spectrum of 4-(4-hydroxy-3-isopropyl-5-((trimethylsilyl)ethynyl)phenyl)butan-2-one (9)

KenCNMRSONOsuccessOct215

zzy-151002-fluoroenone-13C

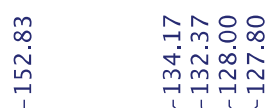

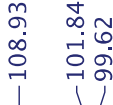

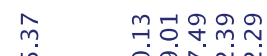

$500 \mathrm{C}$

I

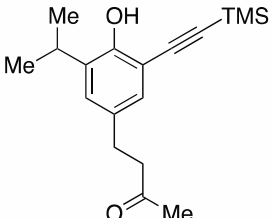

i

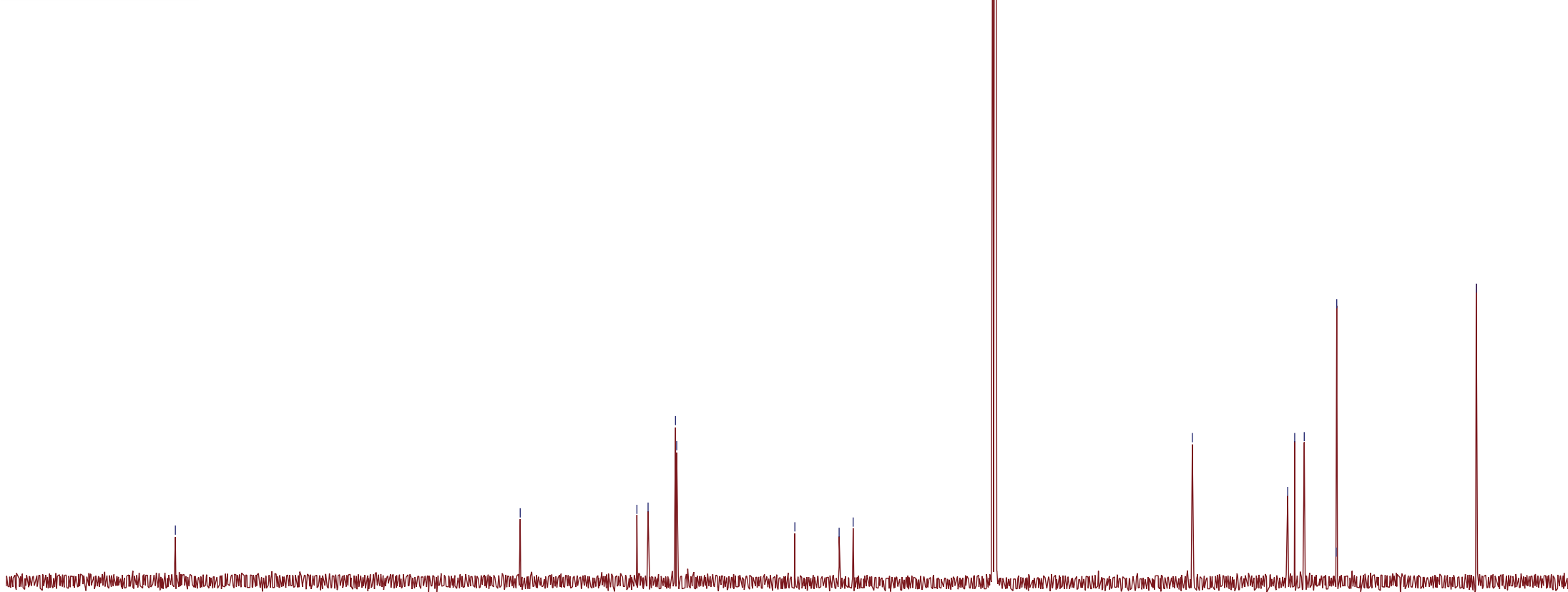

$\begin{array}{lllllll}230 & 220 & 210 & 200 & 190 & 180 & 170\end{array}$

140130

$120 \underset{110}{110} 100$

90

80

70

60

040

30

20

10

$0-10$ 
${ }^{1} \mathrm{H}$ NMR spectrum of 4-(4-((tert-butyldimethylsilyl)oxy)-3-isopropyl-5-((trimethylsilyl)ethynyl)butan-2-one (10)

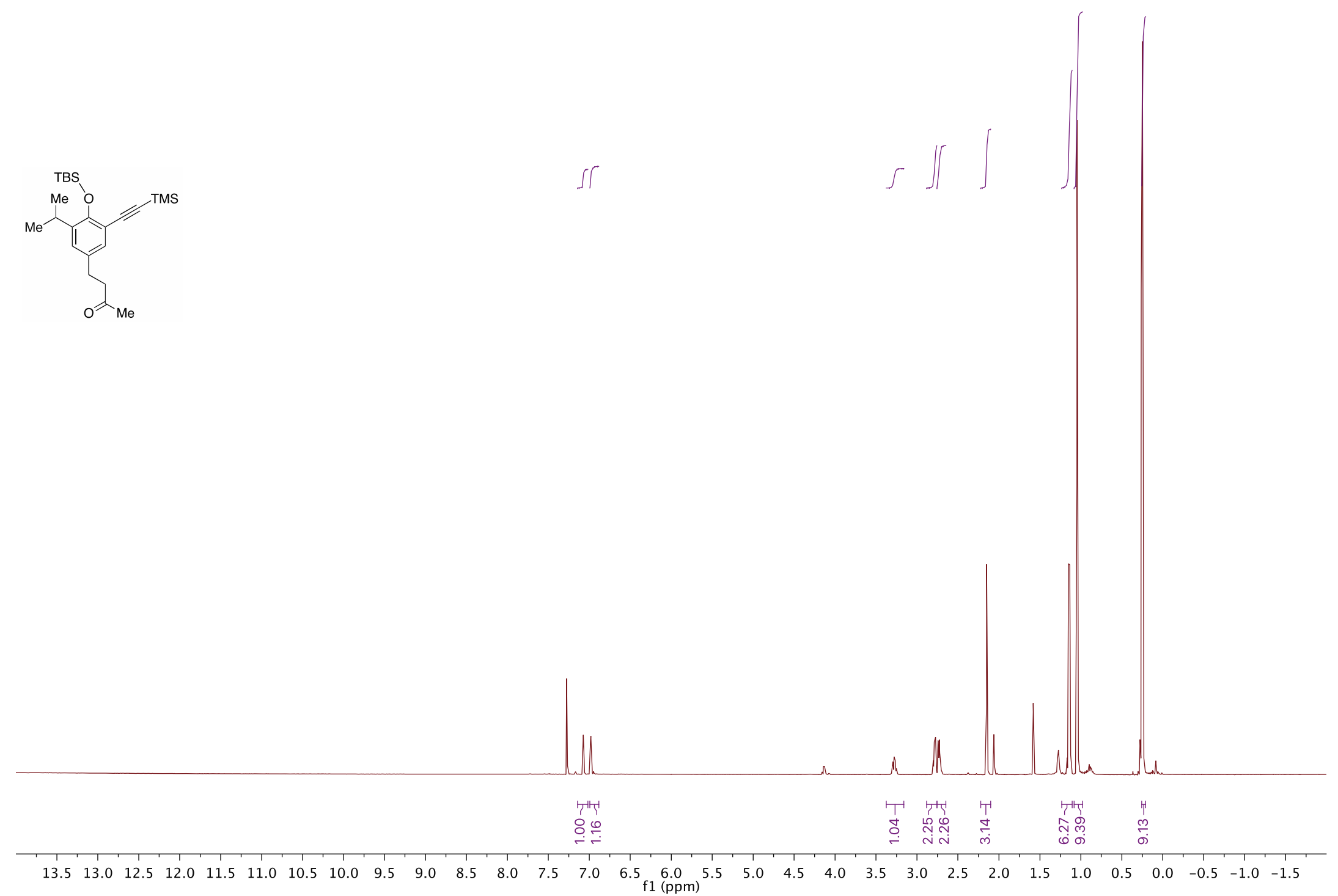


${ }^{13} \mathrm{C}$ NMR spectrum of 4-(4-((tert-butyldimethylsilyl)oxy)-3-isopropyl-5-((trimethylsilyl)ethynyl)butan-2-one

KenCNMROct5 g5TBSProtection $\stackrel{\text { i }}{\infty}$

i্j

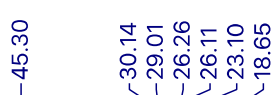

ธัญ กิ
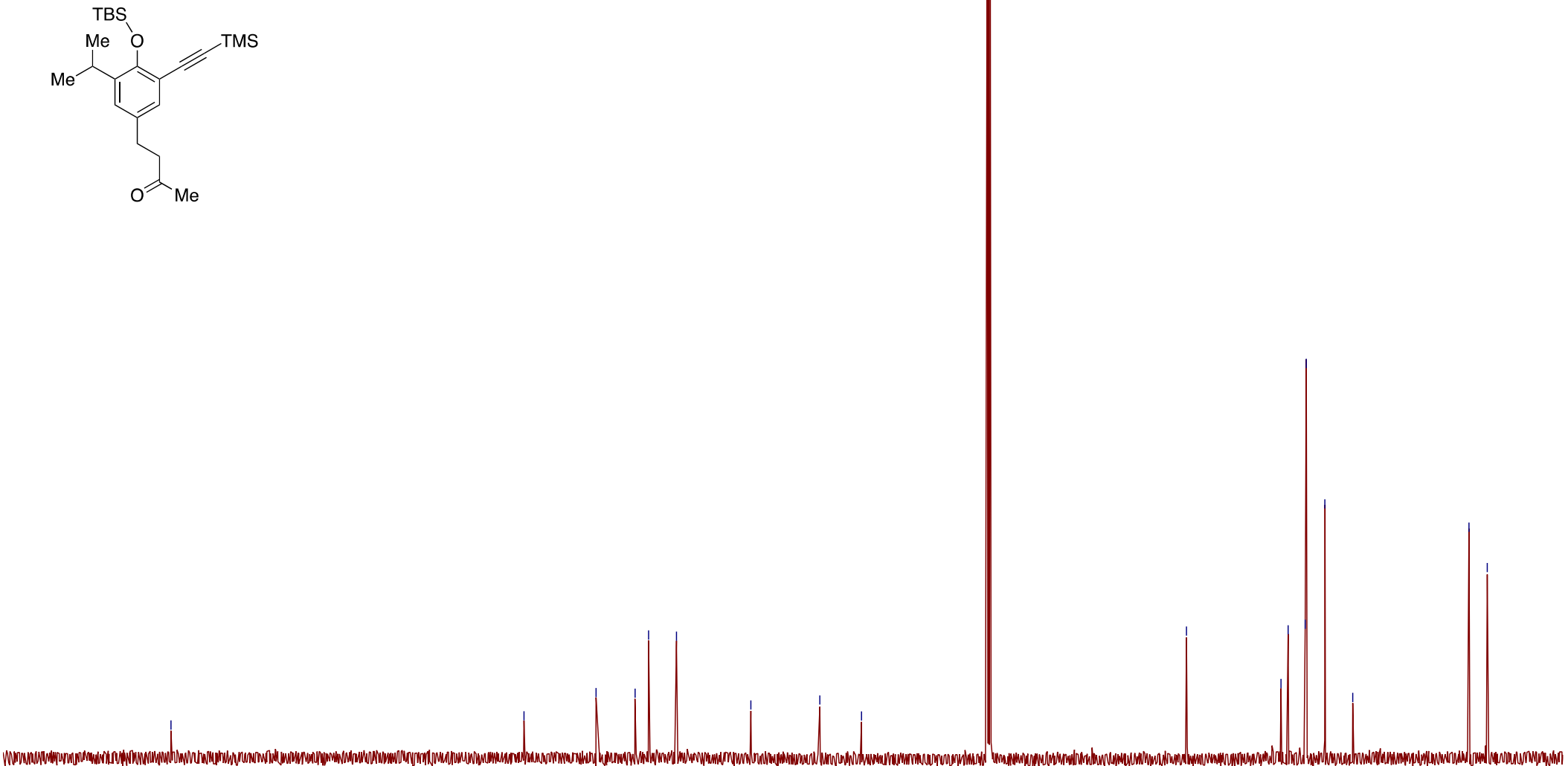
${ }^{1} \mathrm{H}$ NMR spectrum of 4-(4-((tert-butyldimethylsilyl)oxy)-3-isopropyl-5-((trimethylsilyl)rhynyl)phenethyl)-3-methyl-3Hdiazirine (11)

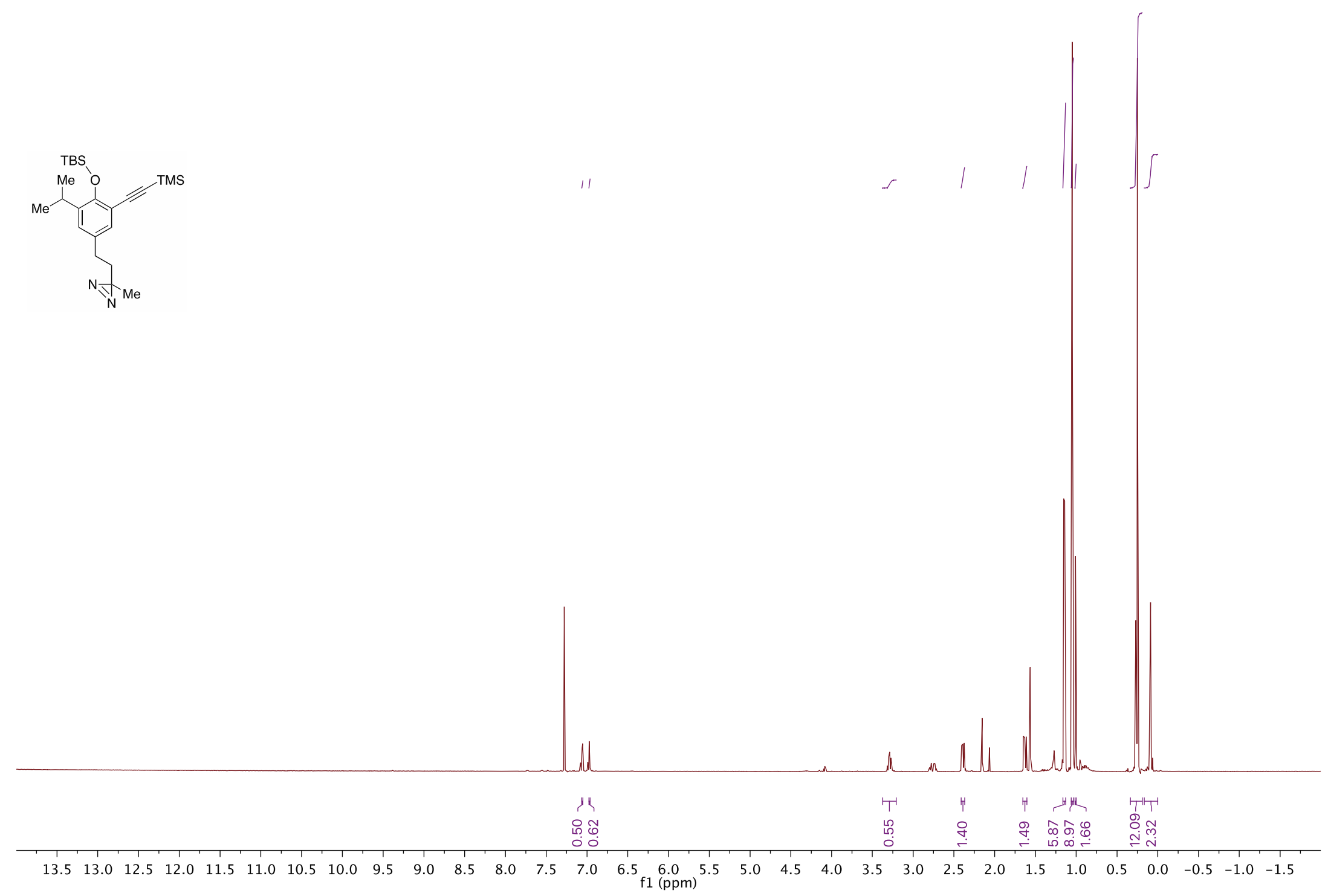


${ }^{13} \mathrm{C}$ NMR spectrum of 4-(4-((tert-butyldimethylsilyl)oxy)-3-isopropyl-5-((trimethylsilyl)rhynyl)phenethyl)-3-methyl-3Hdiazirine (11)
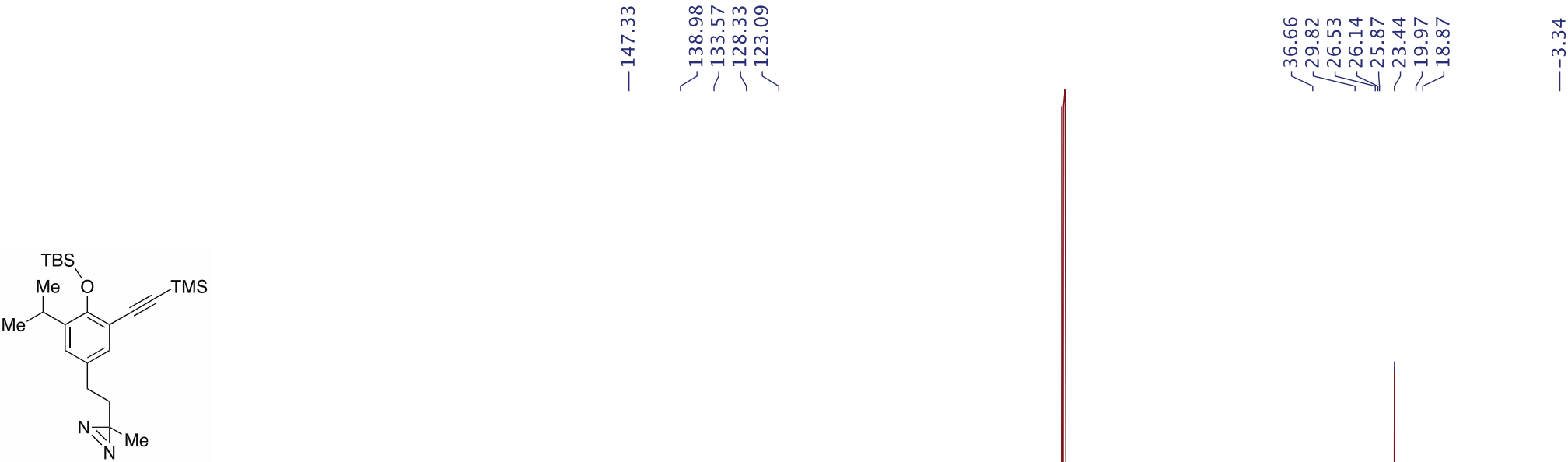
$\begin{array}{lllllllllllll}240 & 230 & 220 & 210 & 200 & 190 & 180 & 170 & 160 & 150 & 140 & 130 & 120 \\ \mathrm{f} 1(\mathrm{ppm})\end{array}$ 0090 80 60 50 $40 \quad 30$ 20 
${ }^{1} \mathrm{H}$ NMR spectrum of 2-ethynyl-6-isopropyl-4-(2-(3-methyl-3H-diazirin-3-yl)ethyl)phenol (12)

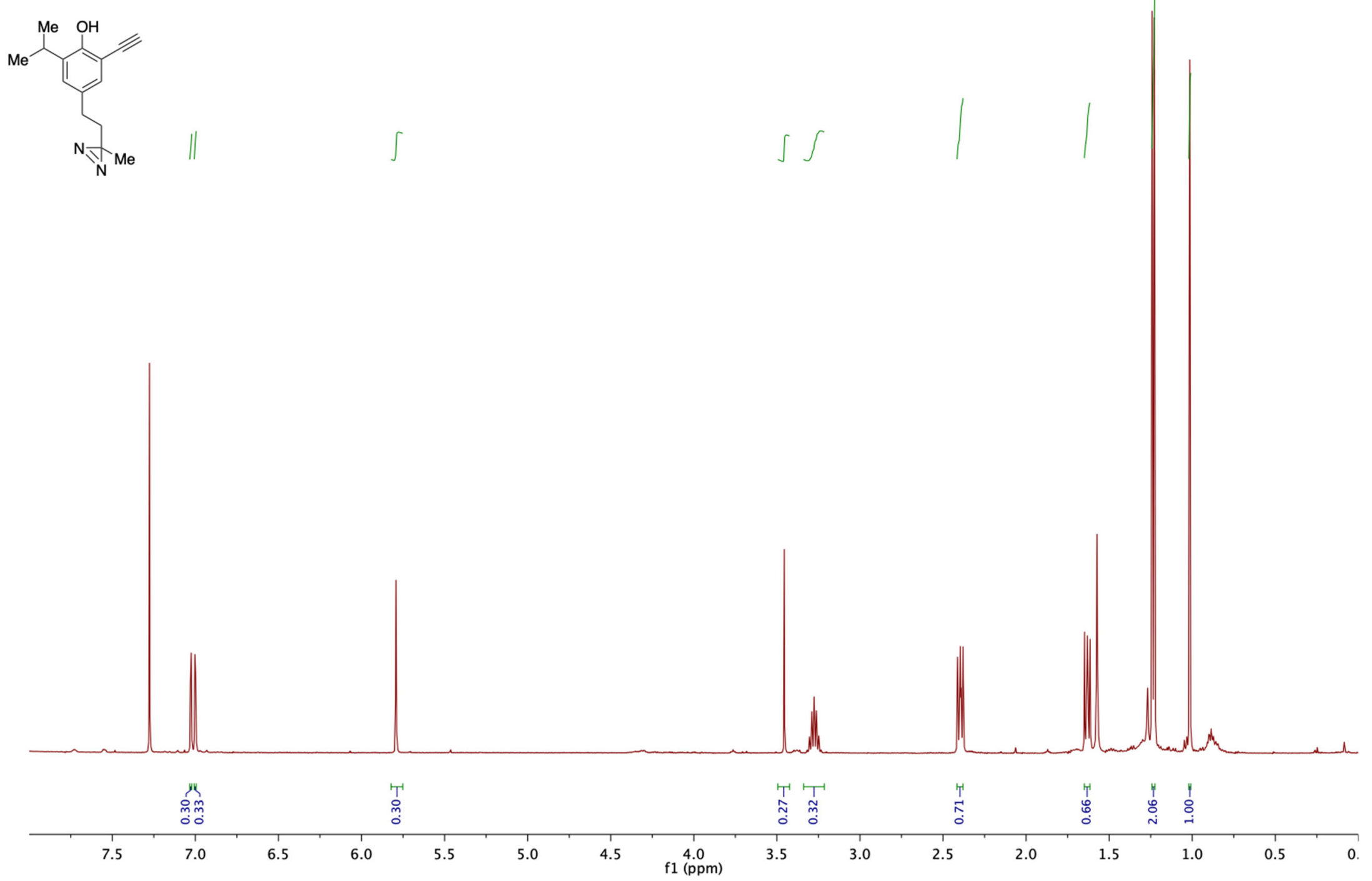


${ }^{13} \mathrm{C}$ NMR spectrum of 2-ethynyl-6-isopropyl-4-(2-(3-methyl-3H-diazirin-3-yl)ethyl)phenol (12)

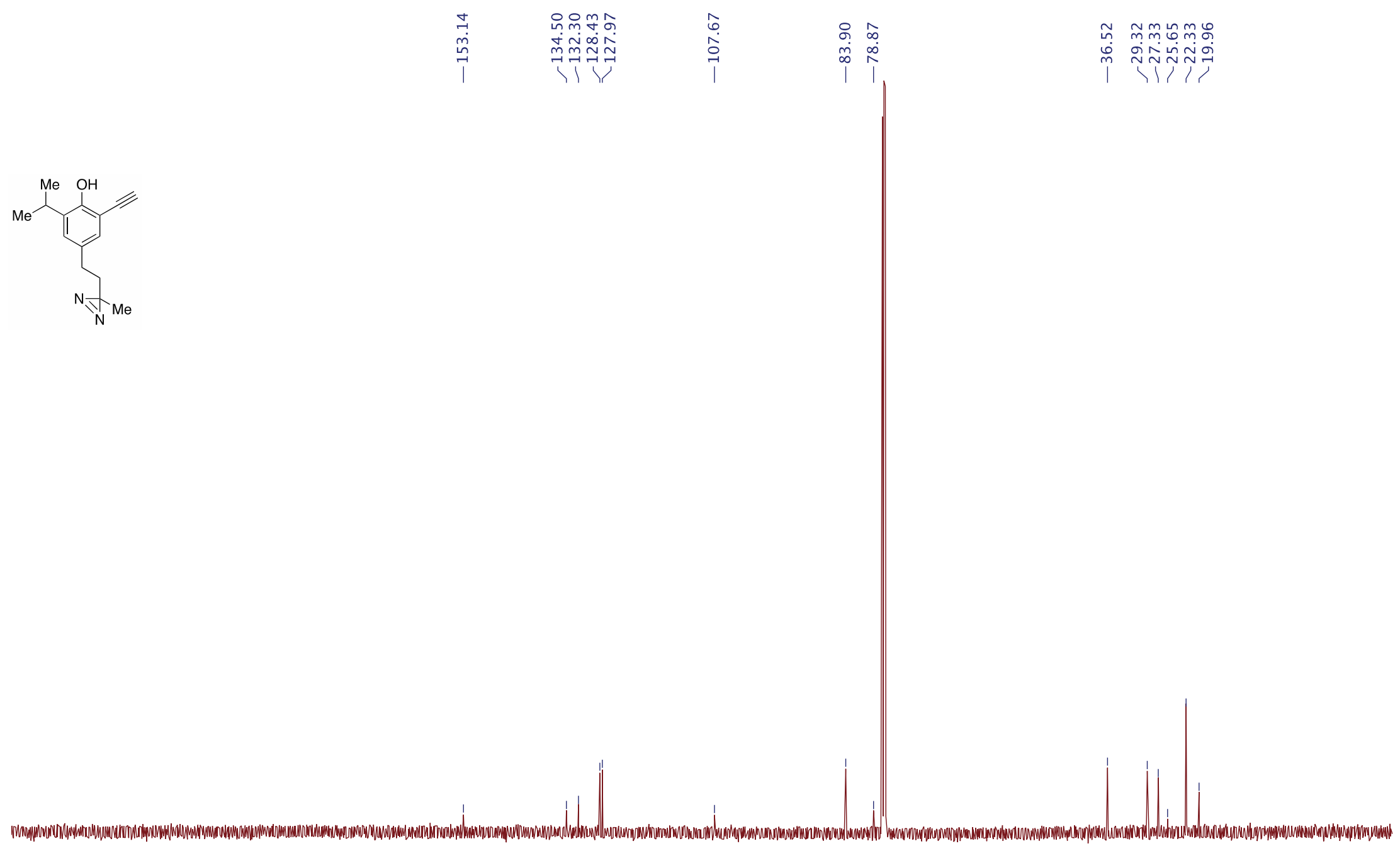

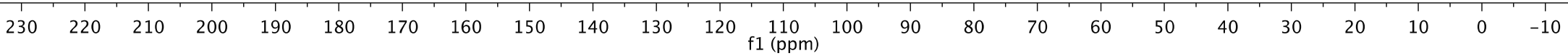


${ }^{1} \mathrm{H}$ NMR spectrum of 4-hydroxy-3,5-diisopropylbenzaldehyde (13)

july1116Aldehyde

FLL-VIII-160-column-3
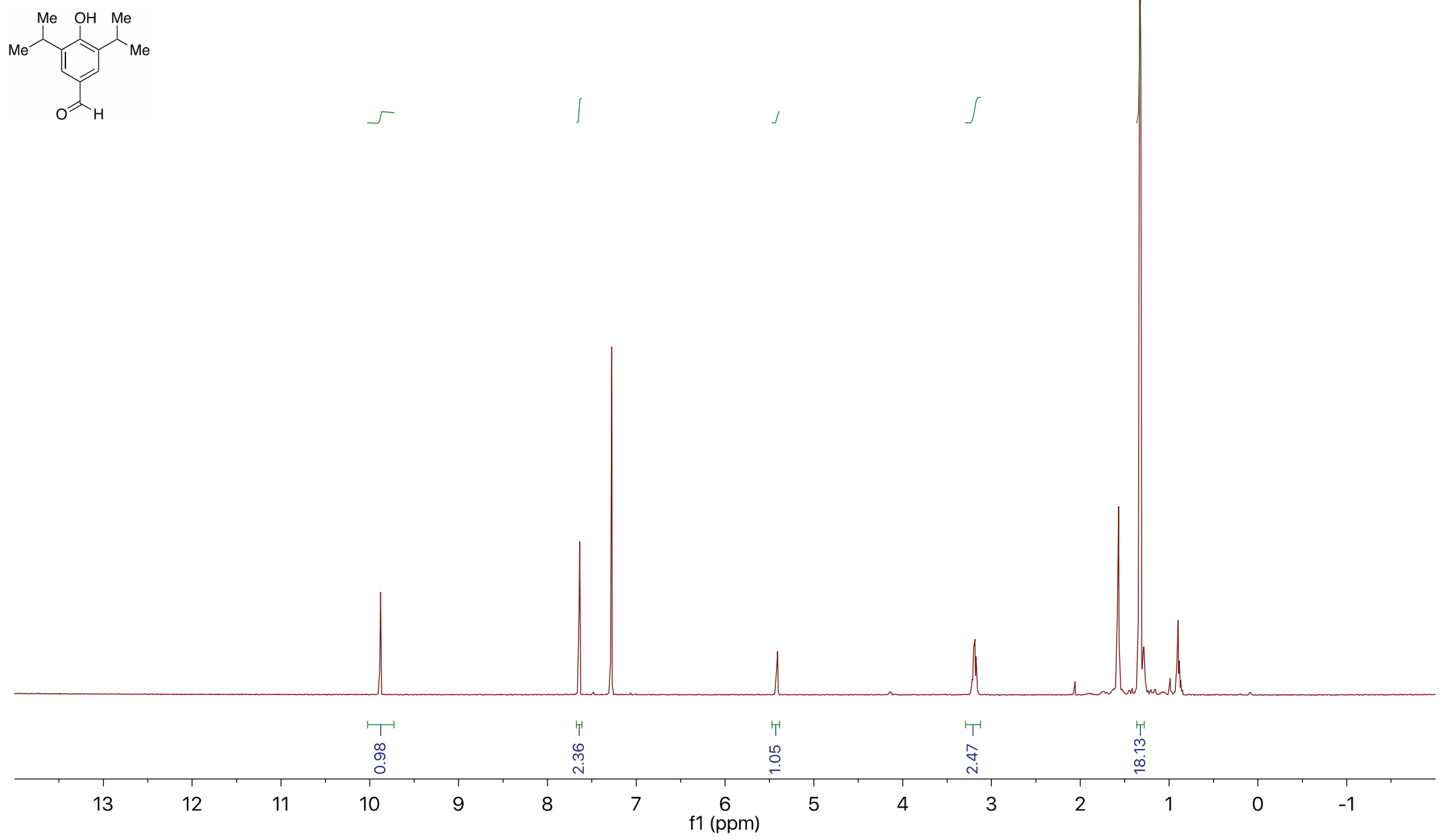
${ }^{13} \mathrm{C}$ NMR spectrum of 4-hydroxy-3,5-diisopropylbenzaldehyde (13)
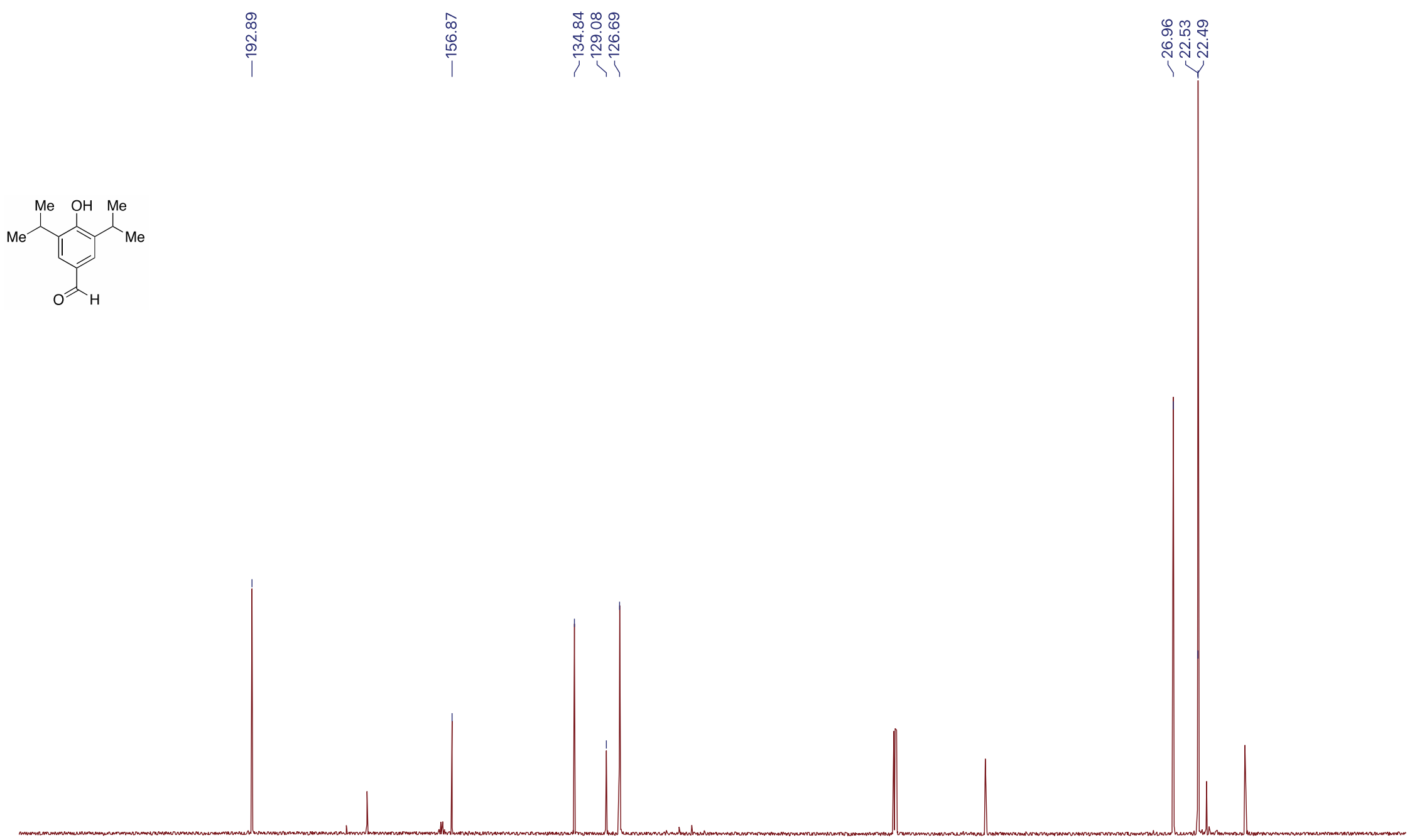

$\begin{array}{lllllllllll}230 & 220 & 210 & 200 & 190 & 180 & 170 & 160 & 150 & 140 & 130\end{array}$ 
${ }^{1} \mathrm{H}$ NMR spectrum of 4-(tert-butyldimethylsilyl)oxy)-3,5-diisopropylbenzaldehyde (14)

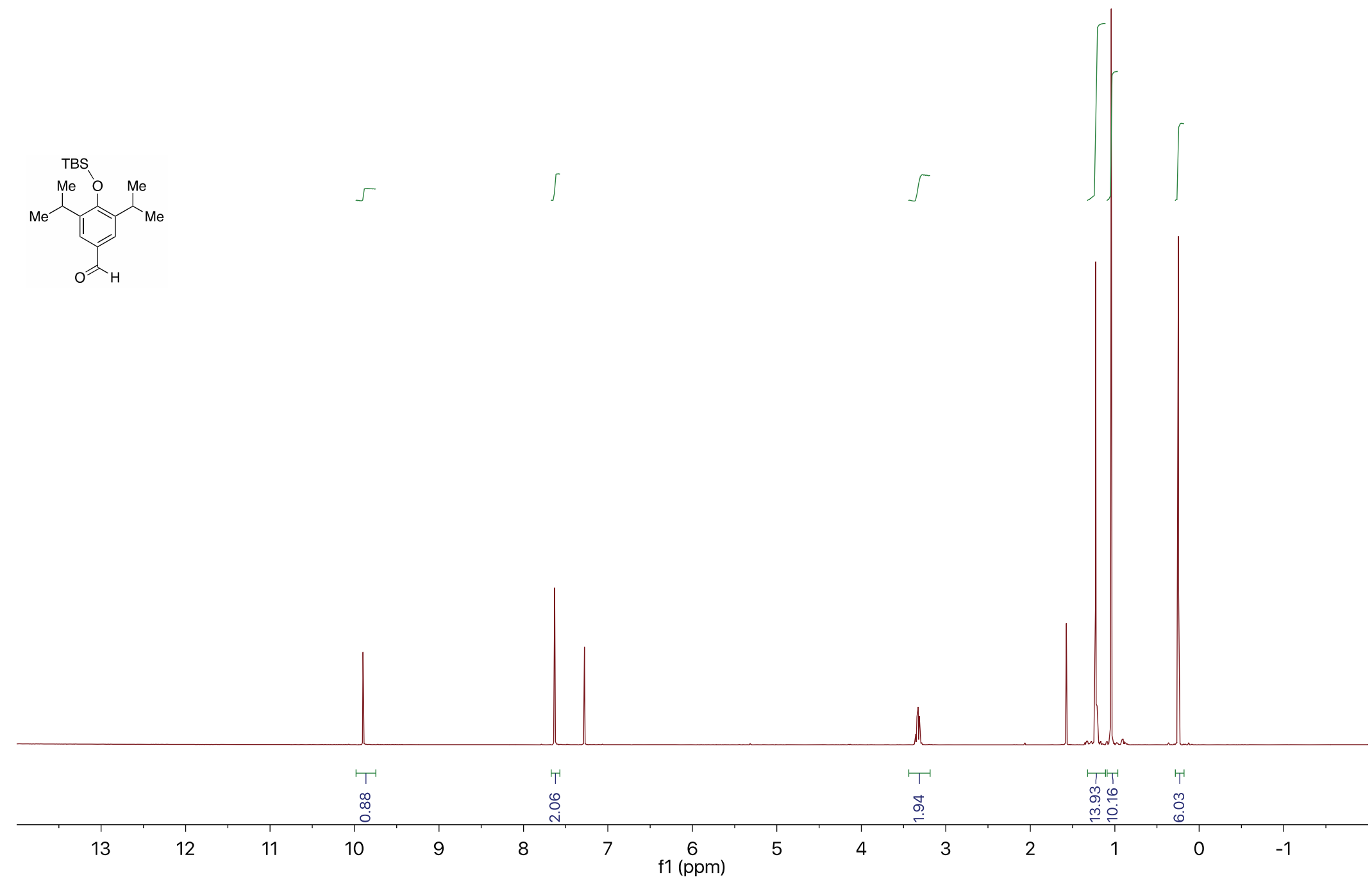


${ }^{13} \mathrm{C}$ NMR spectrum of 4-(tert-butyldimethylsilyl)oxy)-3,5-diisopropylbenzaldehyde (14)

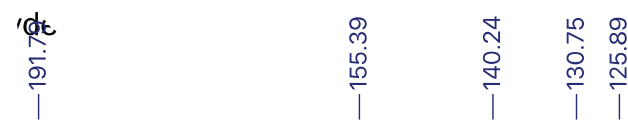

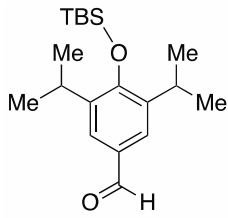

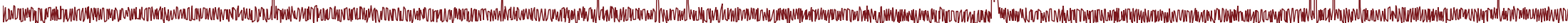


${ }^{1} \mathrm{H}$ NMR spectrum of 1-4-((tert-butyldimethylsilyl)oxy)-3,5-diisopropylphenyl)prop-2-yn-1-ol (15)

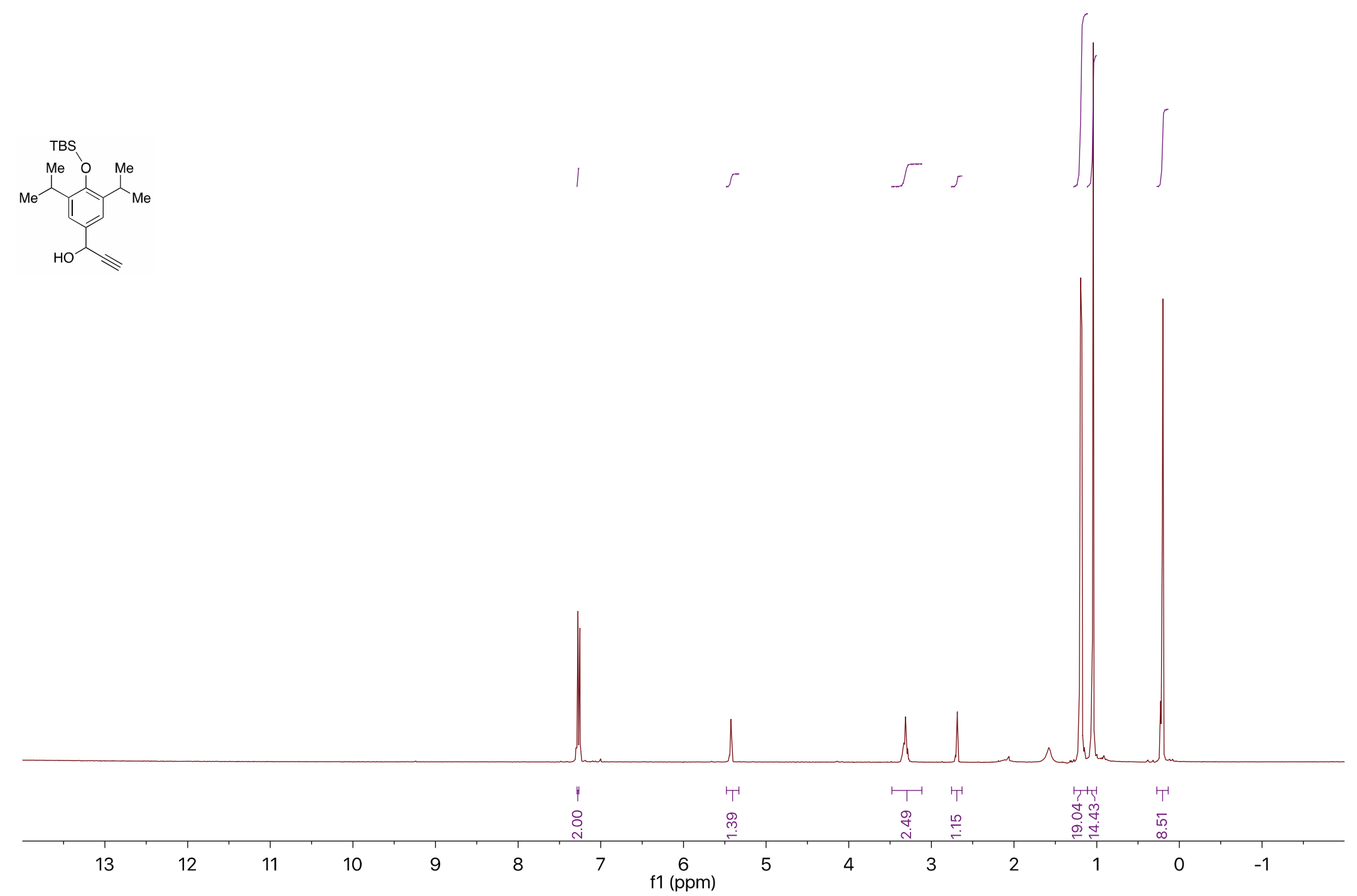


${ }^{13} \mathrm{C}$ NMR spectrum of 1-4-((tert-butyldimethylsilyl)oxy)-3,5-diisopropylphenyl)prop-2-yn-1-ol (15)

$$
\text { î }
$$

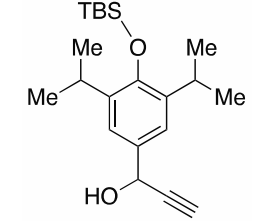

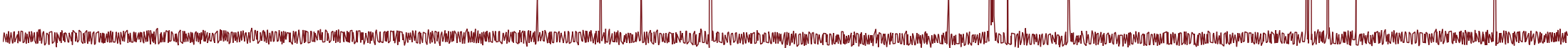


${ }^{1} \mathrm{H}$ NMR spectrum of 4-(4-((tert-butyldimethylsilyl)oxy)-3,5-diisopropylphenyl)hex-5-yn-2-one (16)

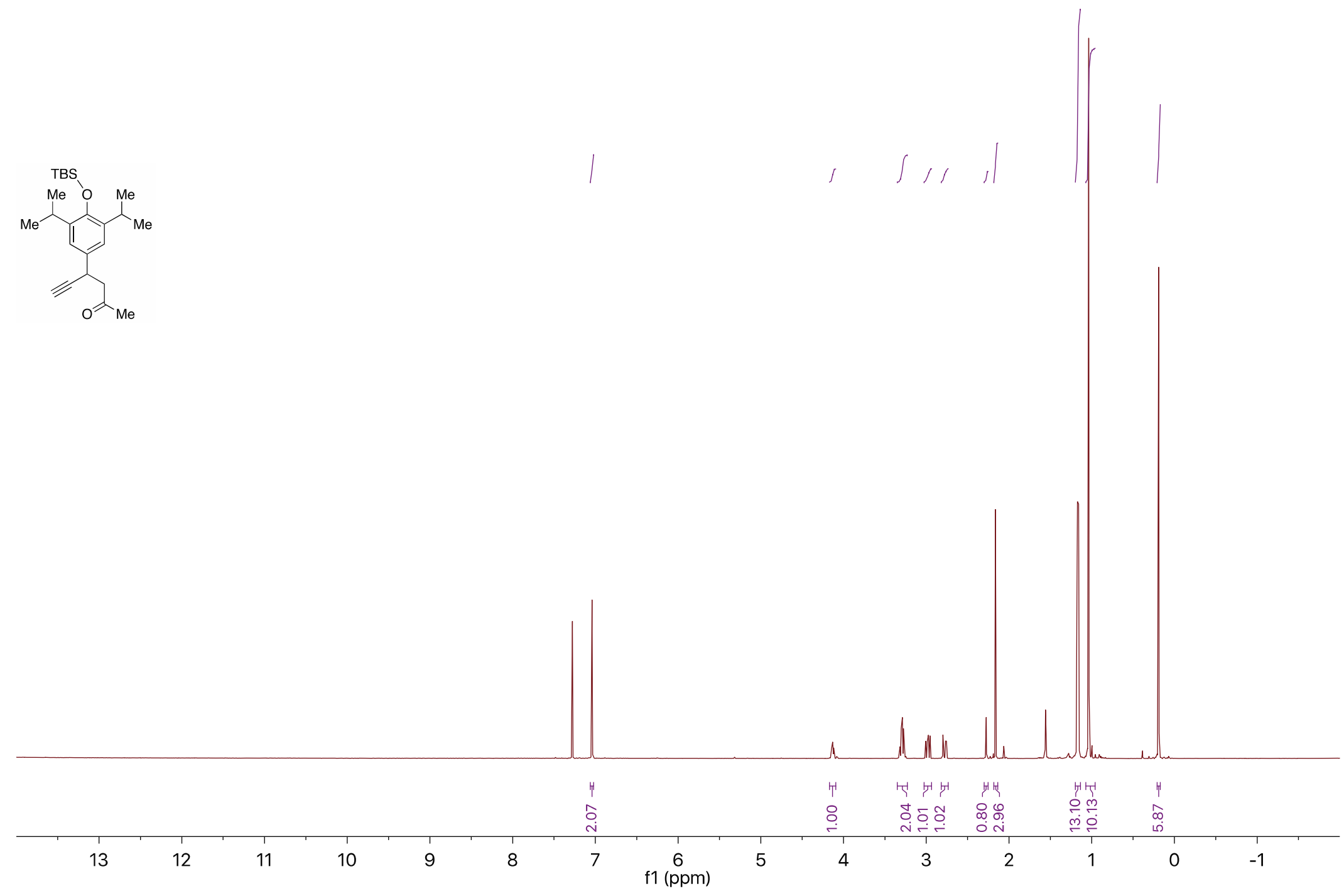


${ }^{13} \mathrm{C}$ NMR spectrum of 4-(4-((tert-butyldimethylsilyl)oxy)-3,5-diisopropylphenyl)hex-5-yn-2-one (16)
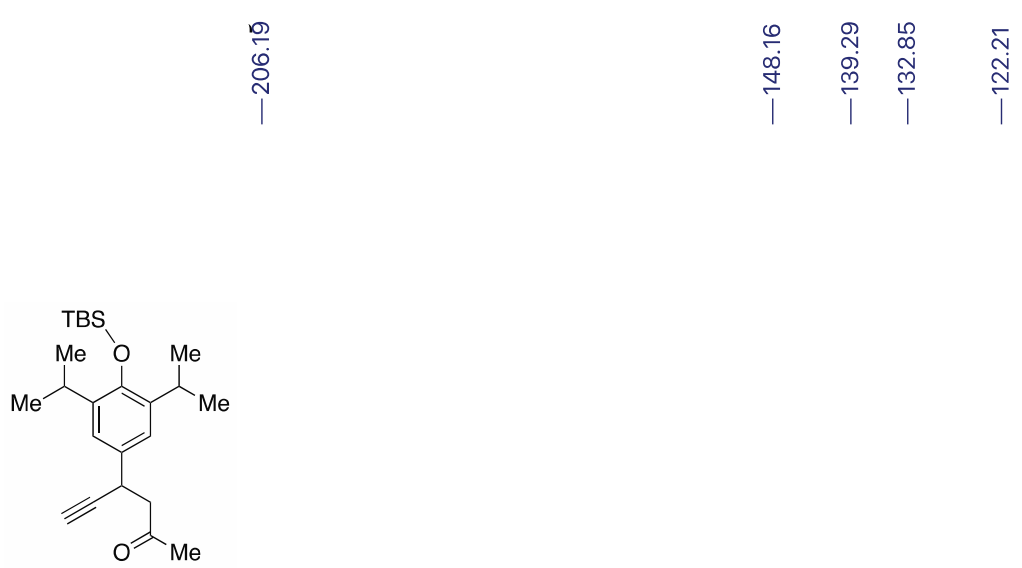

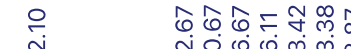

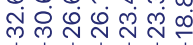

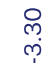

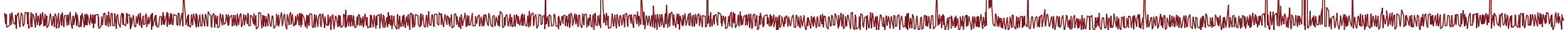


${ }^{1} \mathrm{H}$ NMR spectrum of 3-(2-(4-((tert-butyldimethylsilyl)oxy)-3,5-diisopropylphenyl)but-3-yn-1-yl)-3-methyl-3H-diazirine (17)

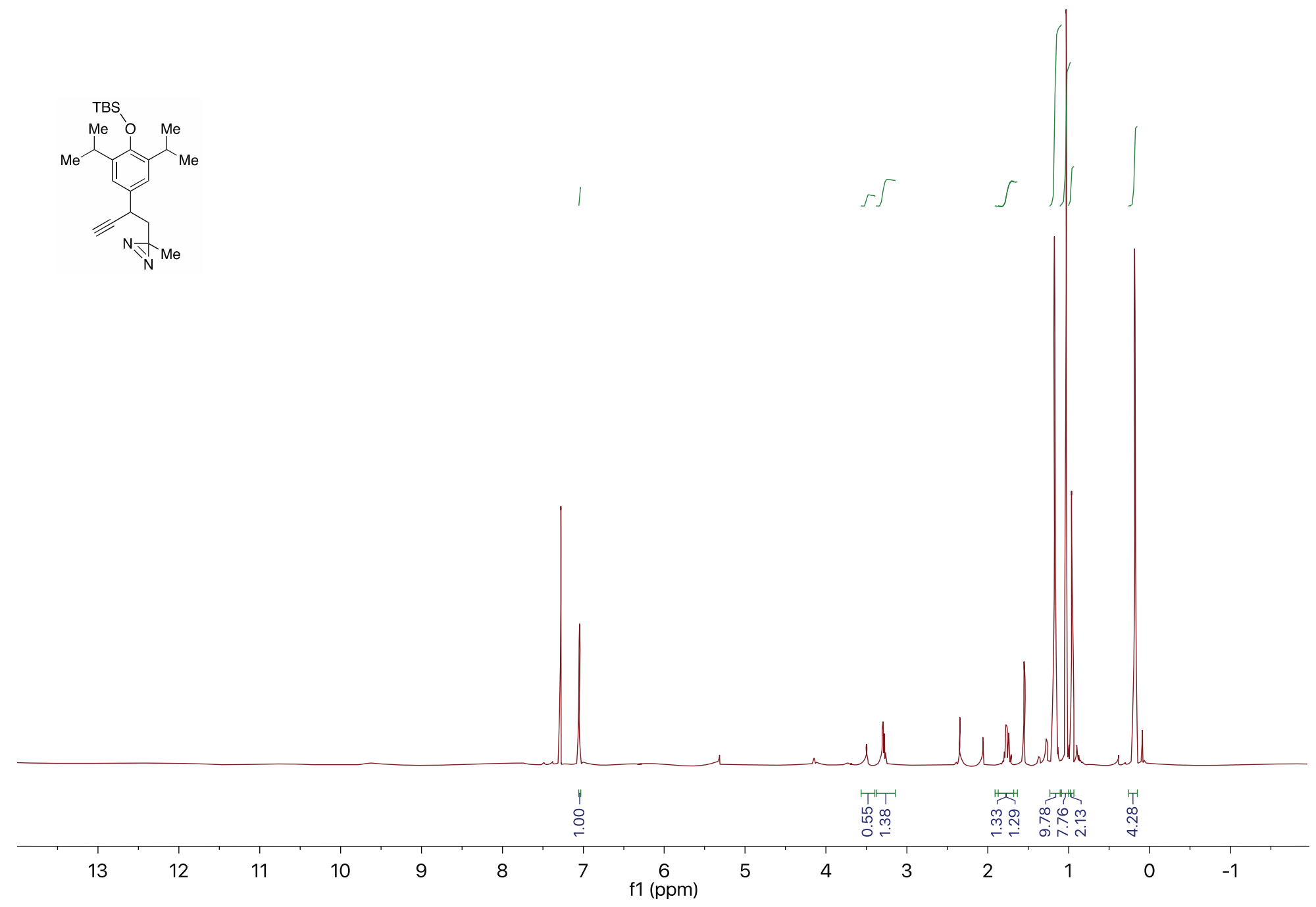


${ }^{13} \mathrm{C}$ NMR spectrum of 3-(2-(4-((tert-butyldimethylsilyl)oxy)-3,5-diisopropylphenyl)but-3-yn-1-yl)-3-methyl-3Hdiazirine (17)

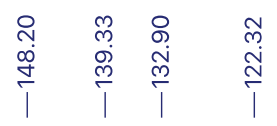

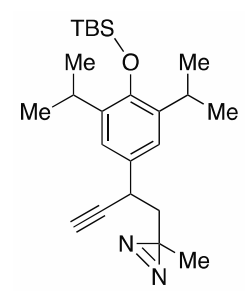

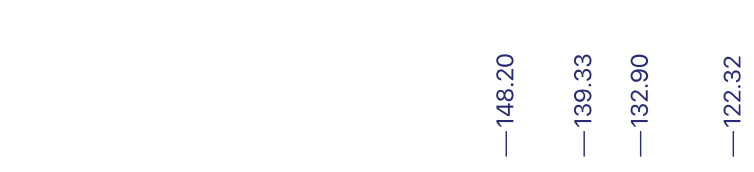

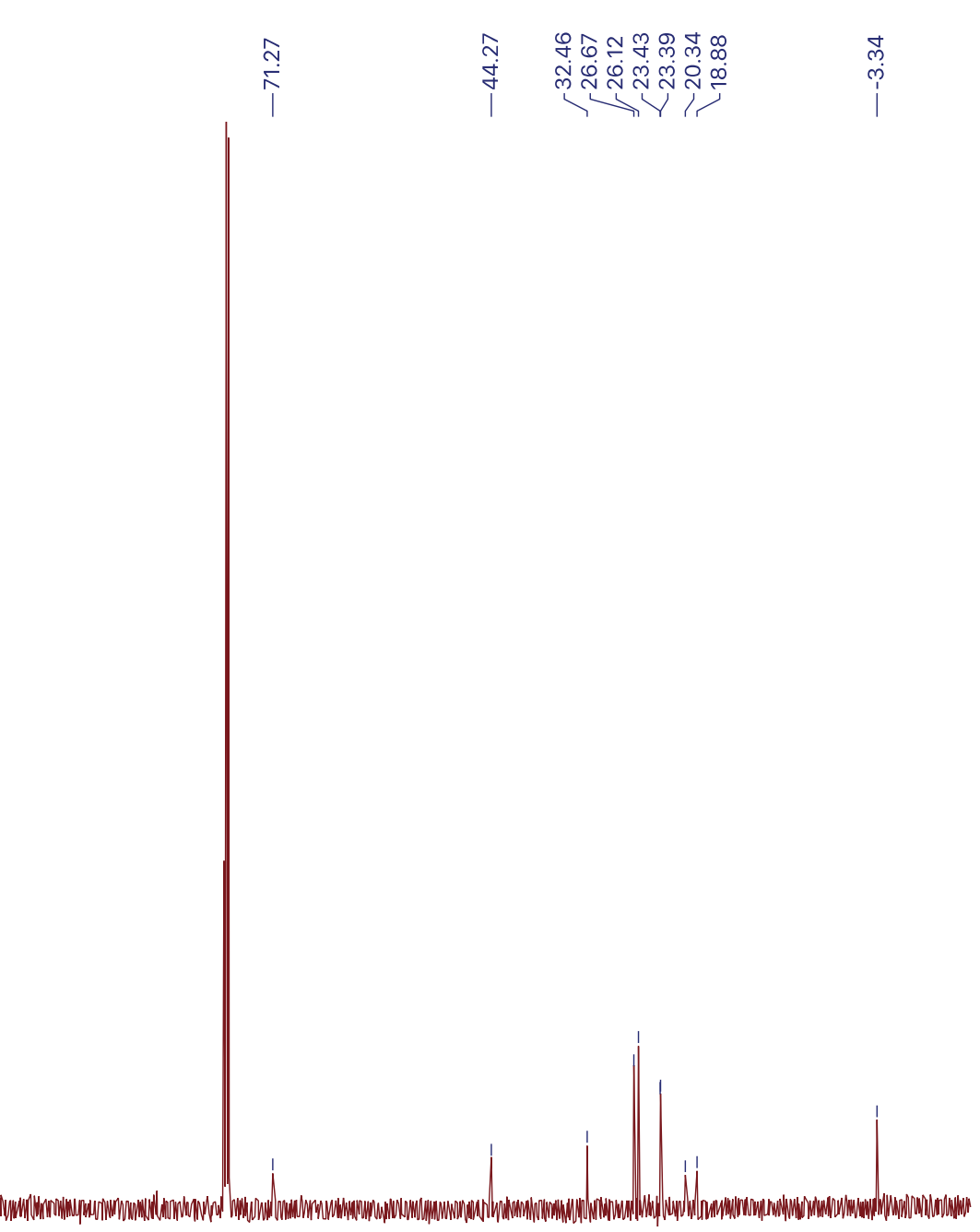

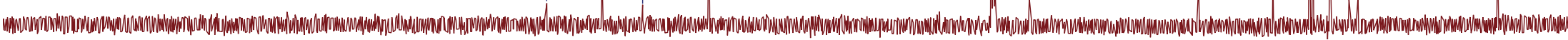

$\begin{array}{lllllllllllllllllllllllll}230 & 220 & 210 & 200 & 190 & 180 & 170 & 160 & 150 & 140 & 130 & 120 & \begin{array}{l}110 \\ \mathrm{f} 1(\mathrm{ppm})\end{array} & 100 & 90 & 80 & 70 & 60 & 50 & 40 & 30 & 20 & 10 & 0 & -10\end{array}$


${ }^{1} \mathrm{H}$ NMR spectrum of 2,6-diisopropyl-4-(1-(3-methyl-3H-diazirin-3-yl)but-3-yn-2-yl)phenol (18)
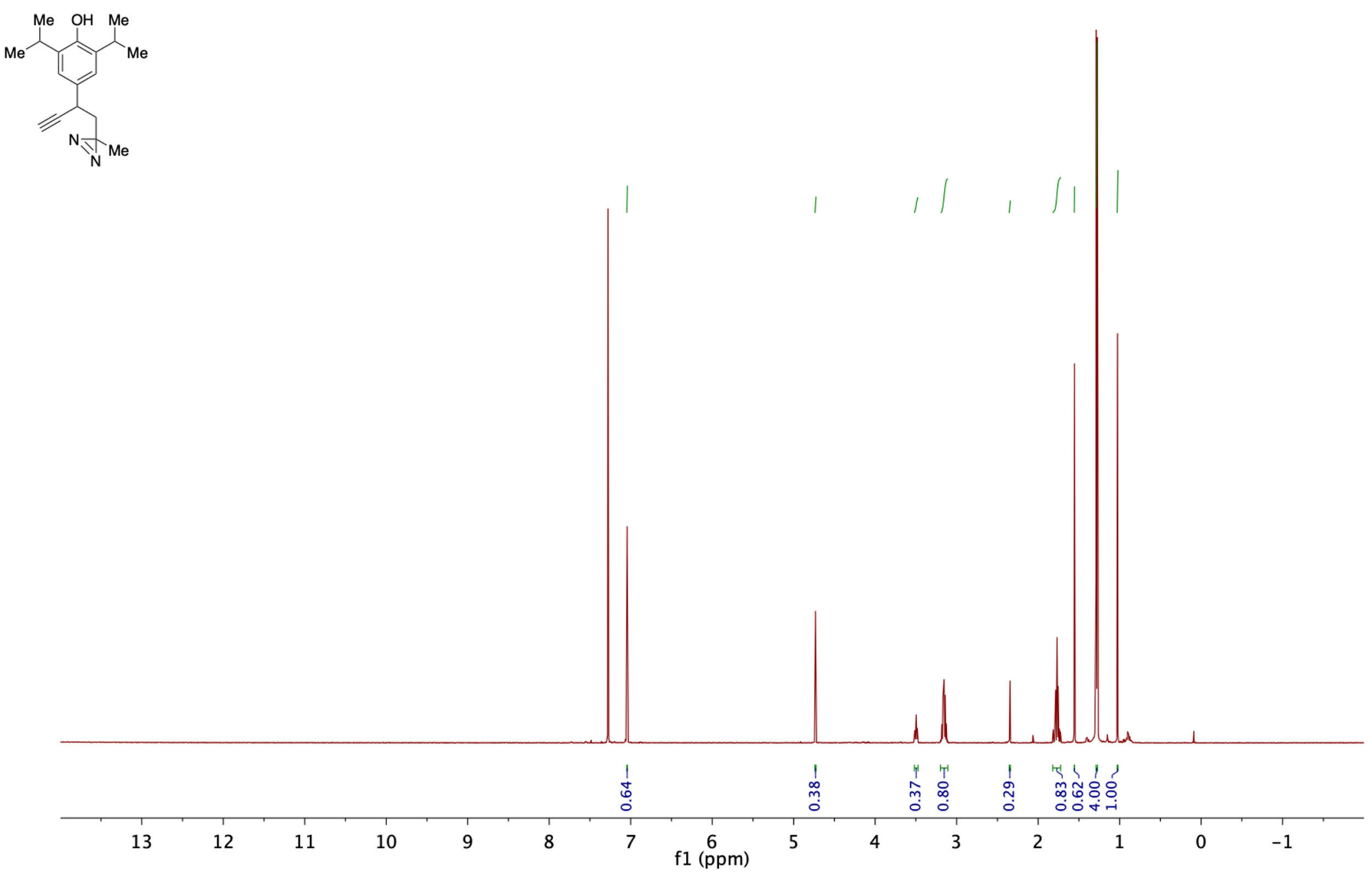
${ }^{13} \mathrm{C}$ NMR spectrum of 2,6-diisopropyl-4-(1-(3-methyl-3H-diazirin-3-yl)but-3-yn-2-yl)phenol (18)
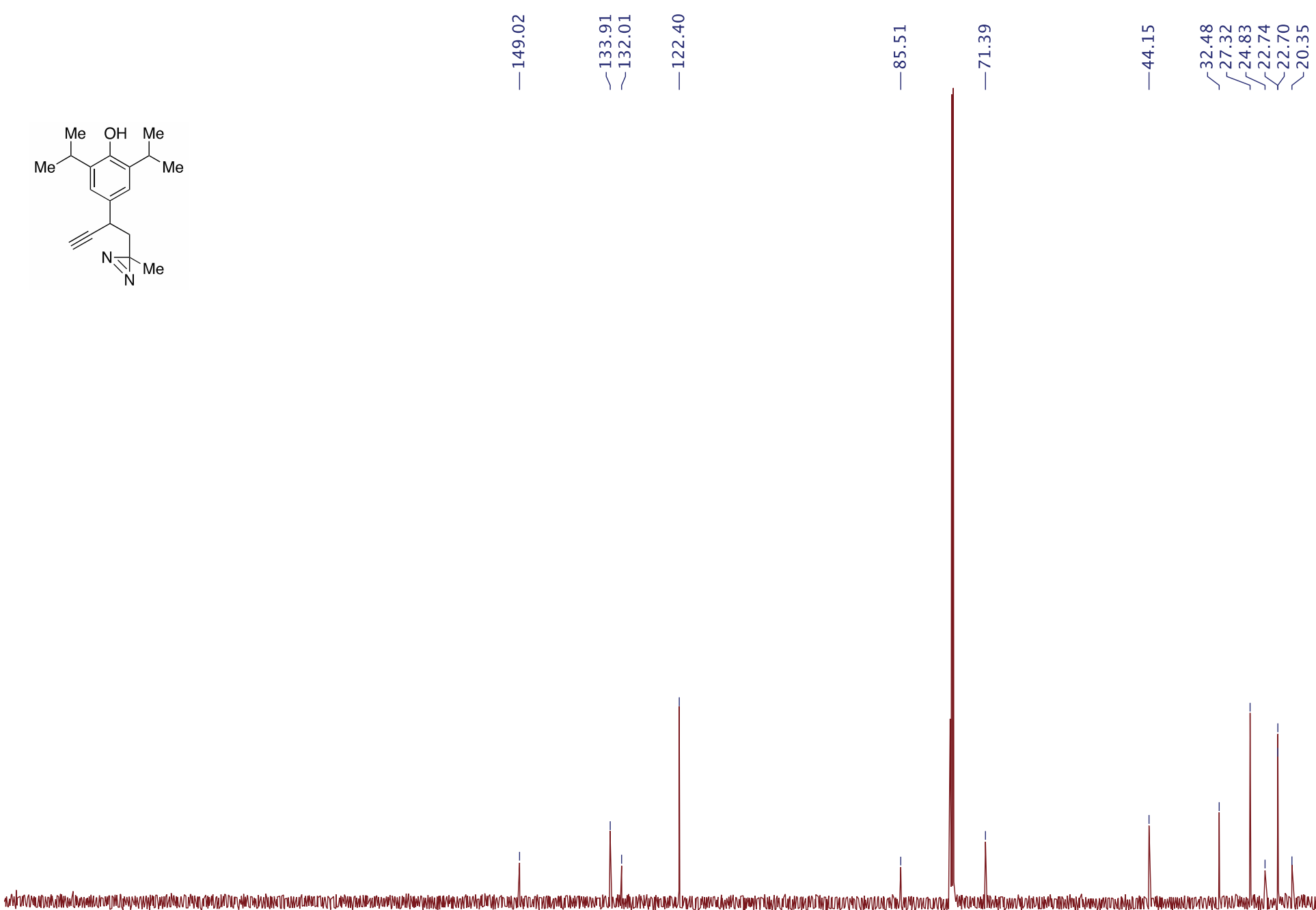

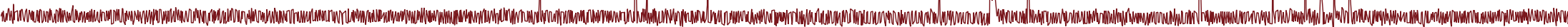

